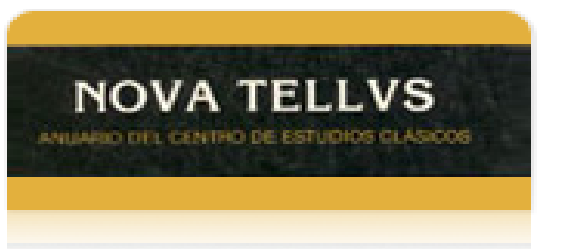

Nova Tellus

ISSN: 0185-3058

novatelu@servidor.unam.mx

Centro de Estudios Clásicos

México

Olivares Chávez, Carolina

La amistad y la gratitud en Jenofonte: dos características del ser humano "bello y bueno"

Nova Tellus, vol. 31, núm. 2, 2014, pp. 65-100

Centro de Estudios Clásicos

Distrito Federal, México

Disponible en: http://www.redalyc.org/articulo.oa? $\mathrm{id}=59137773004$

- Cómo citar el artículo

- Número completo

- Más información del artículo

- Página de la revista en redalyc.org

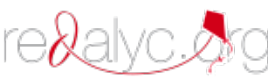

Sistema de Información Científica

Red de Revistas Científicas de América Latina, el Caribe, España y Portugal

Proyecto académico sin fines de lucro, desarrollado bajo la iniciativa de acceso abierto 


\title{
La amistad y la gratitud en Jenofonte: dos características del ser humano "bello y bueno"
}

Friendship and Gratitude in Xenophon's Works:

Two Qualities of the "Fine and Good" Human Being

Carolina Olivares Chávez

Universidad Nacional Autónoma de México

caro.hiparquia@gmail.com

\begin{abstract}
RESUMEN: En este artículo deseo demostrar que, a partir del ambiente de profunda división social que imperaba en la Atenas de su tiempo y de su experiencia personal, Jenofonte adquiere plena conciencia de la función tan relevante que desempeñan la $\phi i \lambda i ́ \alpha$ y la gratitud en la formación del ser humano xàòs $x \dot{\alpha} \gamma \alpha \theta$ ós. Luego de analizar el marco histórico en el que vivió este socrático, así como algunas peripecias que afrontó a lo largo de su existencia, es posible percibir que la gratitud y la amistad ocupan un lugar muy importante en su propuesta de paideia. Por eso, a través de varios de sus protagonistas el estratega trata de inculcar el fomento de la $\phi i \lambda i ́ \alpha$ y de la gratitud; ya que las considera características esenciales del varón "bello y bueno", es decir, del buen ciudadano. Las fuentes principales para sustentar estas ideas son la Anábasis, la Ciropedia, Memorables, el Económico y el Hiparco. ${ }^{1}$ En concreto me referiré a la postura que tenían en torno a estas dos virtudes Agesilao, Ciro el Joven, Ciro el Viejo, el hiparco, Iscómaco y Sócrates.
\end{abstract}

ABSTRACT: In this article I attempt to prove that from both the environment of deep social division that prevailed in Athens and his own personal experience, Xenophon became fully aware of the relevant function that played $\phi \iota \lambda i \alpha_{\alpha}$

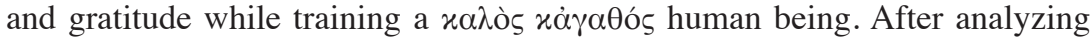
the historical framework in which this socratic disciple lived, as well as some of his personal adventures, it is easy to observe the importance of gratitude and friendship for his proposal of paideia. Through his works's main characters he tries to instill into his audience the qualities of $\phi \iota \lambda i \alpha^{\alpha}$ and gratitude, for he considers them essential features of a good citizen. The main sources supporting these ideas are Anabasis, Cyropaedia, Memorabilia, Oeconomicus and Hipparcus. In this regard, I will pay special attention to the thoughts of Agesilaus, Cyrus the Young, Cyrus the Senior, the hipparcus, Iscomachus and Socrates.

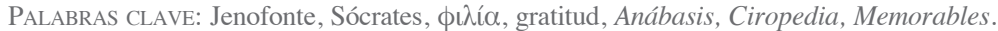

KEY WORDS: Xenophon, Socrates, $\phi \mathbf{\imath} \lambda i ́ \alpha$, gratitude, Anabasis, Ciropaedia, Memorabilia.

RECIBIDO: 1 de diciembre de 2013 - ACEPTADO: 11 de abril de 2014.

${ }^{1}$ Para la mayoría de los textos de Jenofonte sigo la traducción ofrecida por Gredos, mientras en lo relativo al Hiparco me baso en la mía. 
El autor y su época

Jenofonte, quien vivió entre el 430 y el 354 a. C., compuso sus escritos en una etapa de profundos cambios en las costumbres sociales, cuando prevalecía un declive de los valores patrios y del espíritu cívico. ${ }^{2}$ Contempló a su ciudad natal en plena crisis, inmersa en conflictos internos que amenazaban los valores que él tenía en alta estima.

El período comprendido entre fines del siglo $\mathrm{v}$ y mediados del IV a. C. se caracterizó por un fenómeno recurrente: la guerra. La Atenas de aquellos días sufría las secuelas de las Guerras Médicas y de la Guerra del Peloponeso, envuelta en constantes luchas fratricidas. La polis presentaba una imagen de franca decadencia: guerras constantes, desunión y falta de cordialidad entre los diversos estados helénicos, inseguridad política y económica. Los gobiernos oligárquicos y los democráticos cometieron excesos semejantes: persecución política, confiscación de bienes, destierros. Por ende, Jenofonte vivió en una época revuelta y amarga, donde Grecia padeció enfrentamientos bélicos entre ciudades hostiles, en un pueblo empobrecido por esos combates y por los disturbios sociales, por crisis continuas que conmocionaron a las poleis celosas de su independencia. ${ }^{3}$ Desde 431 hasta 346 a. C. la guerra fue permanente, general y multiforme; hubo continuas luchas armadas entre griegos y no griegos, entre las poleis y al interior de cada ciudad. Si bien la guerra daba testimonio de la crisis de la polis, también contribuía a agravar la problemática política, social y económica. ${ }^{4}$

Este autor presenció la Guerra del Peloponeso, el final de la hegemonía ateniense, el nacimiento y la caída del poderío espartano, el efímero ascenso de Tebas y su rápido declive, y también el surgimiento de Macedonia como nueva potencia.

En cuanto al régimen de los Treinta, éste se caracterizó por encarnizados y sangrientos conflictos sociales, y las atrocidades cometidas

${ }^{2}$ Marein 1993, p. 243.

${ }^{3}$ García Gual, introducción a Jenofonte, 1991, pp. 10-11.

${ }^{4}$ Esparta hizo que los atenienses firmaran un humillante tratado, donde les exigía las naves y la demolición de los Muros Largos. Los espartanos instalaron un gobierno oligárquico en Atenas, que pronto dio paso al sanguinario régimen de los Treinta. Si bien los partidarios de la democracia albergaban sentimientos antiespartanos, se mantenía una paz semejante a "un estado de guerra fría" (Salay 2004, pp. 11-12). 
durante dicha tiranía no se olvidaron rápidamente. ${ }^{5}$ Debido a su posición social, es factible que Jenofonte militara en el bando de los tiranos. ${ }^{6}$ Al parecer, participó en las acciones de la caballería, primero bajo los Treinta y luego bajo los Diez, e incluso, en este último gobierno, ocupó el cargo de hiparco. ${ }^{7}$

En 403 a. C., la guerra civil concluyó con la victoria de Trasibulo y la reinstauración de la democracia. A las partes en conflicto se les impuso una amnistía general, que implicaba la renuncia a las persecuciones judiciales con excepción de los delitos de sangre. ${ }^{8}$ Poco después terminó la alianza espartana con Persia, luego de la fallida expedición de los Diez Mil; cabe señalar que Artajerjes II sentía un odio personal contra los espartanos, porque apoyaron la insurrección de su hermano Ciro el Joven. ${ }^{9}$

En 379 a. C., Pelópidas expulsó a los espartanos de Tebas y reconstruyó la Liga Beocia, mientras Jasón hizo lo mismo en Tesalia. Posteriormente, en la Batalla de Leuctra, en 371 a. C., Esparta fue derrotada por Tebas y ya no volvió a tener una significativa presencia militar en los asuntos griegos; de modo que Jenofonte, adulto, fue testigo ocular de la decadencia de las dos máximas potencias griegas: Atenas y Esparta. ${ }^{10}$

Por lo que atañe a la política interior, desde el régimen de los Diez Mil en 410 a. C. hasta la oligarquía de los Cuatrocientos y el represivo gobierno de los Treinta Tiranos, Atenas enfrentó una feroz guerra civil. En un clima violento que se apoderó de toda la polis, resulta lógico que Jenofonte también sufriera ciertas secuelas ocasionadas por ese ambiente de profunda división social. Conviene recordar que él y sus contemporáneos pertenecían a una generación de postguerra, endurecida por la muerte violenta. Ellos habían visto, o conocían de primera mano gracias a los relatos de sus mayores, atrocidades o asesinatos judiciales autorizados por el voto popular; por citar un ejemplo, baste mencionar

${ }^{5}$ Salay, ibid., p. 119.

${ }^{6}$ Canfora 2002, p. 32. Para mayores detalles en torno a la colaboración de Jenofonte con los Treinta y a la masacre en Eleusis, cf. op. cit., pp. 33-34.

${ }^{7}$ Ibid., pp. 35-36. En dichas páginas Canfora alude al "secreto" más importante de la vida de Jenofonte, su desempeño como hiparco y su participación en actos cruentos.

${ }^{8}$ Ibid., pp. 36-38, y Ober 1989, p. 95.

${ }^{9}$ Hornblower 1985, p. 242.

${ }^{10}$ Para otros datos acerca de la crisis política y social que vivió el historiador ateniense, cf. Plácido Suárez 1989, pp. 151-152. 
la ejecución de los seis generales después de la Batalla de las Arginusas en 406 a. C. ${ }^{11}$ De esta manera, Jenofonte, miembro de una familia rica y privilegiada, vivió en una época en que sus conciudadanos ya no estaban conformes con las prerrogativas que siempre se le habían concedido a la aristocracia ateniense..$^{12}$

Por lo que concierne al aspecto económico, se incrementaron los impuestos a causa de los enfrentamientos bélicos. Los atenienses vieron mermadas las rentas de su imperio; en consecuencia, los ricos subsidiaban a los pobres al menos indirectamente. La crisis dio lugar a que, a veces, éstos llevaran a juicio a los ricos, mientras los pobres no podían olvidar que varios aristócratas habían apoyado las tentativas oligárquicas de fines del s. v a. C. Así, el resentimiento y la desconfianza de la clase baja hacia las clases superiores fueron evidentes por su decisión de reducir el apoyo estatal a la caballería ateniense, integrada por los ciudadanos más ricos, soporte de los oligarcas: ${ }^{13}$ en el s. IV a. C., el demos asoció la ostentación, la hybris y el poder antidemocrático con la riqueza. ${ }^{14}$ Una vez terminada la guerra, continuó la problemática social y dicha situación prevaleció durante toda la vida de Jenofonte.

Si bien las observaciones que Pericles hijo y Sócrates hacen en relación con la decadencia militar y moral de los atenienses se refieren al período posterior a la Guerra del Peloponeso, en el fondo las circunstancias son similares a las que prevalecían en tiempos del historiador. Ante la crisis tan apremiante el filósofo comenta:

Me doy cuenta de que es ésta la situación, pero creo que en este momento la ciudad está en disposición más propicia para un hombre de bien que asuma el mando, pues la confianza engendra descuido, indolencia e indisciplina, mientras que el miedo nos hace más atentos, más voluntariosos y más disciplinados. ${ }^{15}$

El sabio dice explícitamente que, como los atenienses se confiaron en su superioridad, se descuidaron y vinieron a menos. ${ }^{16} \mathrm{~A}$ través de un diá-

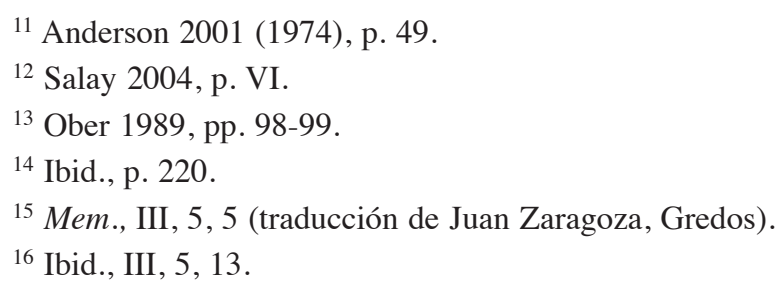


logo entre Sócrates y Pericles hijo, el historiador da el contexto de lo que se vivía en la Atenas de su época: ${ }^{17}$ en resumen, la $x \alpha \lambda$ oxả $\alpha \theta \theta i ́ \alpha$ no se encontraba allí, pues sus conciudadanos ya no respetaban a los mayores, despreciaban a los ancianos, incluso a sus progenitores, ya no se adiestraban físicamente, además de descuidar sus cuerpos, se burlaban de los que sí se ejercitaban; desobedecían a las autoridades y se ufanaban de menospreciarlas; lejos de convivir con armonía y ayudarse mutuamente, no colaboraban ni en las cosas de interés común, se envidiaban unos a otros, se la pasaban en muchísimos pleitos públicos y privados, trataban los asuntos de la polis como si no les incumbiera; todo esto ocasionaba desgaste y perjuicio para Atenas, pues prevalecían el odio y la discordia entre los ciudadanos. Si bien las personas de clase humilde se esmeraban para obedecer a sus dirigentes, los hoplitas y los caballeros, la gente de mejor nivel social, eran los más indisciplinados de todos. Se enfatiza que en el ejército nadie fomentaba la sensatez, la obediencia y la disciplina; al respecto, Sócrates atribuía ese caos a que en dicha institución ocupaban el mando las personas menos aptas, porque la mayoría de los generales eran unos improvisados. ${ }^{18}$

\section{Jenofonte y su experiencia personal}

El historiador vivió en un tiempo en el que reinaba la descomposición interna de la sociedad y de las relaciones humanas, inclusive de la familia; como consecuencia de la disgregación política cada vez más profunda y la frecuente intervención de los sicofantas, se volvió asfixiante la inseguridad del individuo aislado. ${ }^{19}$ Ante tales circunstancias, el concepto de la amistad adquiere singular importancia, incluso es sintomática de la época de guerra. ${ }^{20}$ En este sentido, gracias a la philía se produce confianza y solidaridad, sentimientos esenciales para la unión.

A mi juicio, tras el contacto con Sócrates y sus ideas morales, el historiador experimentó en persona la trascendencia real de muchos preceptos socráticos, tales como el fomento de la amistad y la gratitud; de

\footnotetext{
${ }^{17}$ Ibid., III, 5, 15-19.

18 Ibid., III, 5, 21.

19 Jaeger 1944, p. 68.

${ }^{20}$ Ibid., p. 67. Allí se advierte que la philía tiene sus antecedentes en la forma de vida socrática.
} 
modo que, al integrarse al ejército de Ciro el Joven, obligado por la guerra Jenofonte adoptó varias virtudes de su maestro, las puso en práctica y las reafirmó por convicción propia. Más tarde, sus penalidades como soldado en Asia Menor, su servicio en Lacedemonia y su estrecho contacto con los peloponesios le permitieron examinar diferentes patrones educativos hasta que él mismo, congruente con su naturaleza de hombre de acción y conocedor de la problemática que aquejaba a Atenas, recomienda sólo los principios que considera más útiles y que le consta que funcionan, pues los extrae de su experiencia directa.

Uno de los episodios más significativos en su vida y, por ende, en su ideología, fue su incorporación al contingente mercenario de Ciro el Joven. Desde la primavera del 401 hasta marzo del 399 a. C., transcurrieron los dos años más difíciles de su existencia. Jenofonte tuvo un ejército valiente; pero integrado por hombres de la peor calaña, ambiciosos, intrigantes, oportunistas, desleales. ${ }^{21}$ Por mi parte, sostengo que sus desventuras con los Diez Mil, su trato directo con gente de otras razas y su prolongado exilio de casi veinte años fueron determinantes para que se percatara de la verdadera importancia que tienen la amistad y la gratitud no sólo en época de conflictos bélicos, sino también en la vida cotidiana.

El contacto personal de Jenofonte con el general Clearco le permitió darse cuenta de que ni siquiera en la milicia conviene aplicar siempre mano dura, pues el exiliado lacedemonio conseguía infundir en los presentes la idea de que había que obedecerlo, y lo lograba con la firmeza de su carácter. Tenía voz áspera y un aspecto que inspiraba temor; castigaba siempre con rigor y era a veces colérico, hasta el grado de que en ocasiones se arrepentía. Castigaba por convicción, porque consideraba que de nada sirve un ejército indisciplinado. Creía que los soldados debían temerle más a su jefe que a los enemigos, para que de inmediato lo obedecieran. En las circunstancias adversas siempre lo elegían sus hombres, ya que su rostro se tornaba sereno y su severidad se convertía en firmeza ante el contrario. En tales momentos lo veían como su salvación más que como objeto de temor; pero, superado el peligro, muchos lo abandonaban, porque siempre era duro y cruel. ${ }^{22}$ No había personas

${ }^{21}$ Carlos García Gual aclara que este singular ejército estaba compuesto por los peores granujas de Grecia, cf. Jenofonte 1991, p. 27.

${ }^{22}$ An., II, 6, 12. 
que lo siguieran por amistad o por simpatía. ${ }^{23}$ Sabía hacerse obedecer sin miramientos por quienes se veían obligados a estar bajo sus órdenes. Tenía arrojo frente a los enemigos, y el temor de ser castigados por él hacía que sus hombres fueran disciplinados. Éstas eran sus cualidades como jefe. ${ }^{24} \mathrm{El}$ historiador afirma que Clearco, modelo de educación espartana, "ejercía el mando llevando en la mano izquierda la lanza y en la derecha un bastón. Y si le parecía que alguno [...] era perezoso, lo sacaba aparte y le daba los golpes que merecía". ${ }^{25}$ En síntesis, este jefe de los mercenarios griegos personificaba todos los atributos bélicos de un buen líder, pero dejaba mucho que desear en el trato personal.

En contraste con el férreo temperamento del general estaba el delicado Próxeno de Beocia, el amigo de Jenofonte que lo invitó a unirse a la expedición; dicho estratega tenía treinta años cuando lo mataron y había sido alumno de Gorgias de Leontino, por lo que representaba la educación sofística. Acerca de su carácter, era muy suave en el trato con los mercenarios, tenía modales muy refinados, era capaz de mandar a hombres de alcurnia; pero no podía infundir en sus soldados ni respeto ni temor a su persona, pues ellos no lo obedecían, incluso conspiraban en su contra y lo manipulaban. ${ }^{26}$

$\mathrm{Al}$ ver que ninguna de las conductas arriba señaladas eran adecuadas, el ateniense aprende de sus vivencias y propone una actitud intermedia, más apegada a la realidad; por sus amargas experiencias durante la expedición de los Diez Mil, sabe que esto repercute directamente en las insidias y traiciones a las que principalmente los jefes están expuestos. En este sentido, el autor personifica un modelo de educación socrática: al igual que su maestro, considera que es mejor ganarse a los hombres mediante la benevolencia y el ejemplo, demostrando en todo momento su pericia y don de mando, con amistad. De allí que para él la obediencia no carezca de valor si, más que el resultado de la violencia, es un acto voluntario. ${ }^{27}$ En suma, el escritor sostiene que, si bien el castigo es el recurso adecuado para hacerse obedecer a la fuerza, hay un modo

${ }^{23}$ Ibid., II, 6, 13. Por el contrario, Jenofonte destaca a cada instante la importancia de tratar bien a los soldados e incluso recomienda ganarse su aprecio.

${ }^{24}$ Ibid., II, 6, 6-15.

${ }^{25}$ Ibid., II, 3, 10 (traducción de Ramón Bach Pellicer, Gredos).

${ }^{26}$ Ibid., II, 6, 18-20.

${ }^{27}$ Ibid., III, 3, 9, e Hipparch, VI. 
más rápido y efectivo para ganarse la obediencia voluntaria, porque los hombres obedecen sumamente gustosos a quien consideran más diestro que ellos. ${ }^{28}$

En cuanto a su comportamiento en el campo de batalla, en la medida de sus posibilidades alaba y honra a los valientes. ${ }^{29}$ Por lo que concierne a usar su fortuna para recompensar a los demás, Jenofonte está consciente de que quienes reciban más de lo establecido lo verán como un honor $\mathrm{y}$, naturalmente, estarán muy agradecidos con quien se los otorgue. ${ }^{30}$ El autor expresa que las personas a las que uno trata con generosidad siempre están dispuestas a servir con gusto a su bienhechor, ya sea por el solo acto de ser tratados generosamente, como porque piensan que vale la pena que los consideren "un depósito de agradecimiento". 31

En su papel de líder, Jenofonte está en todas partes para ayudar a los soldados, que lo llaman "padre" y "benefactor"; trata de imitar a su héroe favorito, que es Odiseo en el país de los lotófagos. ${ }^{32}$ En su calidad de dirigente, el historiador está consciente de que es ignominioso llevar a buen término los asuntos personales y desentenderse de los problemas que aquejan a los demás, sobre todo cuando uno es estimado por ellos. ${ }^{33}$

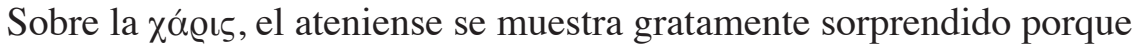
los persas les enseñan a los niños la gratitud, y a propósito narra esto:

juzgan también por la acusación que más odio produce entre los hombres y que es menos objeto de juicio, la ingratitud; $y$, al niño de quien deciden que pudiendo demostrar agradecimiento no lo hace, también a éste le dan un fuerte castigo, pues piensan que los desagradecidos son los más negligentes respecto con los dioses, sus padres, su patria y sus amigos, y es opinión generalizada que a la ingratitud, sobre todo, acompaña la desverguienza, pareciendo que ésta, a su vez, es la máxima guía para todos los actos inmorales. ${ }^{34}$

${ }^{28}$ Cyr., I, 6, 21. El autor añade que quien sólo se preocupa por aparentar destreza, termina por demostrar que es un fanfarrón (I, 6, 23).

${ }^{29}$ An., VIII, 8, 25-26.

${ }^{30}$ Cyr., I, 6, 11 .

${ }^{31}$ Ag., IV, 4.

${ }^{32}$ An., III, 2, 25.

${ }^{33}$ Ibid., VII, 7, 40.

${ }^{34}$ Cyr., I, 2,7 (traducción de Ana Vegas Sansalvador, Gredos). Al igual que en el ámbito civil, la gratitud o disposición amistosa es un aspecto imprescindible en la milicia; porque si no existe se tiende al divisionismo, a la deserción y, peor aún, a la traición. De 
Al respecto, la ingratitud, pese a no ser ilegal es injusta: el hombre justo no perjudica a nadie y, además, ayuda a todo aquel que tiene trato con él; desde esta perspectiva, ser justo equivale a ser benefactor. ${ }^{35}$

A mi juicio, la importancia que tiene la "disposición amistosa", entendida como gratitud, se deriva de los desagradables sucesos que Jenofonte vivió en Asia Menor, donde en varias ocasiones enfrentó a un ejército enardecido por las insidias de algunos de sus propios hombres y hasta de un adivino de su ejército. ${ }^{36}$ El historiador manifiesta la decepción más grande por la ingratitud de su gente cuando se defiende de las acusaciones por haber golpeado a varios de sus soldados, ante lo cual observa con un dejo de tristeza:

Sin embargo [...] me sorprende que, si me enemisté con alguno de vosotros, lo recordéis y no lo calléis, y que, en cambio, si a alguno presté ayuda durante el invierno o lo aparté del enemigo, o a un enfermo o desvalido ayudé, nadie se acuerde de esto, como tampoco nadie recuerde las veces en que he alabado al que se conducía bien o he honrado en la medida de mis fuerzas, a los valientes. Sin embargo, es más hermoso, justo, piadoso y grato recordar los bienes que los males. ${ }^{37}$

Con estas palabras el autor derrota a sus detractores.

Otra muestra de lo relevante que era para él la amistad en la milicia es cuando los lacedemonios van a buscar al ejército griego y Seutes les da una pésima referencia de Jenofonte, al decir que "en lo demás no era malo, pero que era amigo de los soldados y, por este motivo, le iba peor", lo cual desconcertó muchísimo a los espartanos. ${ }^{38}$ Más tarde, una vez reunido el ejército griego, un hombre se quejó de él y lo culpó por haberlos obligado a las penalidades de la travesía y por enriquecerse

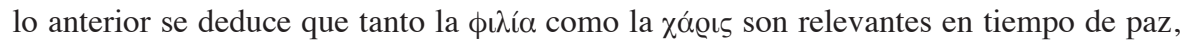
pero se vuelven vitales en época de guerra.

${ }^{35}$ Strauss 2005, pp. 116-117.

${ }^{36}$ An., V, 6, 28-33, donde se defiende de las injurias de Silano; refuta las intrigas de Neón, lugarteniente de Quirísofo, y su principal argumento es su sinceridad para con sus soldados y que deja hablar a cualquiera que tenga algo que contribuya al beneficio de todos (V, 7, 5-12); prosigue su defensa en V, 7, 5-34. En todos los casos condenan a los culpables y exoneran a Jenofonte.

${ }^{37}$ Ibid., V, 8, 25-26 (traducción de Ramón Bach Pellicer, Gredos).

${ }^{38}$ Ibid., VII, 6, 3-4. 
a sus expensas, incluso pidió que fuera lapidado y castigado por esos males, todo esto ante los enviados espartanos ${ }^{39}$ Sin embargo, a través de un largo discurso el estratega ateniense realizó su defensa ${ }^{40}$ al manifestar honestamente su tristeza ante la ingratitud de sus tropas, y exclamar: "todo puede esperarse del género humano, puesto que yo soy acusado ahora por vosotros de algo que considero en conciencia como la mejor prueba de mi buena voluntad hacia vosotros". ${ }^{41}$ Luego añadió que tenía la impresión de que eran absolutamente ignorantes o demasiado ingratos. ${ }^{42}$ Entre otras cosas, les recuerda que ahora tienen la gloria de haber vencido a los tracios contra quienes emprendieron su expedición, que lo calumnian, que siempre los ha defendido, a pesar de sus muestras de odio hacia él, a quienes ni siquiera en este momento crítico renuncia a hacerles el bien que esté a su alcance. ${ }^{43}$ Concluye al aseverar que, si ejecutan lo que piensan, habrán matado a un hombre que ha velado muchas noches por ellos, que ha compartido con sus hombres muchas fatigas y peligros, cuando le tocaba y cuando no, y que cuando los dioses eran propicios ha levantado muchos trofeos de los bárbaros, y ha luchado con tesón entre ellos. ${ }^{44}$ Por último, agrega: "Ciertamente no ocurría lo mismo cuando estabais en dificultades, ;oh prodigios de memoria!, sino que incluso me llamabais padre y me prometíais tenerme siempre presente como bienhechor". ${ }^{45}$ Ante tan acalorado debate, los dos legados lacedemonios defienden a Jenofonte, pues reconocen que el único defecto que Seutes le vio fue que era muy amigo de los soldados. ${ }^{46}$

${ }^{39}$ Ibid., VII, 6, 9-10.

${ }^{40}$ Ibid., VII, 6, 11-38.

${ }^{41}$ Ibid., VII, 6, 11 (traducción de Ramón Bach Pellicer, Gredos). Jenofonte está totalmente de acuerdo en que los persas apliquen castigos a las personas ingratas.

42 Ibid., VII, 6, 23.

${ }^{43}$ Ibid., VII, 6, 31-35.

${ }^{44}$ Ibid., VII, 6, 36.

${ }^{45}$ Ibid., VII, 6, 38 (traducción de Ramón Bach Pellicer, Gredos).

${ }^{46}$ Ibid., VII, 6, 39. Otras alusiones a la amistad se encuentran en VII, 7, 40, y VII, 7, 41-42, donde se expresa que "para un hombre, sobre todo si es jefe, no hay bien más hermoso ni más espléndido que virtud, justicia y generosidad. Pues quien posee estas cualidades es rico, porque tiene muchos amigos; es rico, además, porque otros quieren llegar a ser sus amigos también y, si triunfa, tiene personas para compartir su satisfacción, y, si fracasa, no le falta quien le ayude" (traducción de Ramón Bach Pellicer, Gredos). Por último, Jenofonte piensa que todos los hombres creen que se debe demostrar afecto a la persona de la que reciben bienes (VII, 7, 46). 
La amistad y la gratitud en algunos personajes jenofónticos

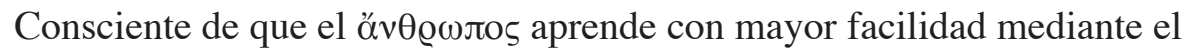
ejemplo y preocupado por sustentar firmemente sus ideas pedagógicas, en sus textos Jenofonte presenta personajes cuya función es servir como modelos educativos. Luego de analizar a varios de sus protagonistas, es manifiesto que, lejos de plantear ideas aisladas, el historiador promueve de manera congruente y sistemática una serie de virtudes a través de las cuales es factible inferir su propuesta de $\pi \alpha \iota \delta \varepsilon i ́ \alpha$, cuyo eje central

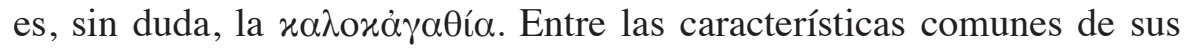
personajes principales, están la philía y la gratitud, como se verá a continuación. ${ }^{47}$

\section{Agesilao}

Desde que Jenofonte le transfirió los mercenarios de Ciro, entabló una estrecha amistad con este rey espartano. ${ }^{48}$ En el encomio que le com-

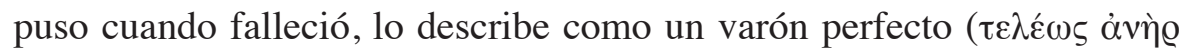

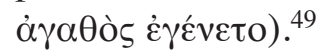

Su comportamiento era tal que los griegos de Asia Menor lo llamaban "padre y compañero". ${ }^{50} \mathrm{Su}$ amor hacia su patria fue tan grande que incluso cuando la vejez le impedía servir a pie o como jinete,

pero veía que la ciudad necesitaba dinero [...], se impuso a sí mismo la obligación de conseguirlo; y lo que podía, lo realizaba quedándose en su patria, pero lo que era oportuno, no dudaba en buscarlo, ni se avergonzaba de salir

${ }^{47} \mathrm{Si}$ bien Jenofonte no desconoce la función educativa que la pederastia desempeñaba en la formación del ciudadano ateniense, a mi juicio a lo largo de sus obras le otorga mayor valor educativo a la philía, entendida como amistad y camaradería, al trato amable entre los hombres que - al igual que lo hacían las relaciones pederásticas contribuyen a fomentar la emulación. Éste es un aspecto recurrente en su producción literaria y se torna una cualidad indispensable en aquellos personajes que él propone como modelos de conducta (cf. Olivares Chávez 2014, pp. 141-263). En torno a esto, "la philía, desde el punto de vista de la moral comunitaria, es un sentimiento que goza de mayor aprobación social que el éros" (Vallejo Campos 2009, p. 73).

${ }^{48}$ D. L., II, 51-52; el biógrafo afirma que en ese tiempo los atenienses sentenciaron a Jenofonte al destierro por laconismo.

${ }^{49}$ Ag., I, 1.

${ }^{50}$ Ibid., I, 38. 
como embajador en lugar de estratego, siempre que lo consideraba útil para su ciudad. ${ }^{51}$

Agesilao comprendió que, si triunfaba al procurar el bien de su patria y de sus conciudadanos y castigaba a sus rivales, entonces en verdad ganaría las competencias más hermosas e importantes, y sería muy famoso tanto en vida como en muerte. ${ }^{52}$ Siempre combatió en primera fila por su polis y por la Hélade entera contra los adversarios más poderosos, ${ }^{53}$ y servía a su patria de tal forma que había adquirido amigos serviciales sobre todo con la obediencia, también logró que sus soldados fueran al mismo tiempo sumisos y afectuosos con él. ${ }^{54}$ En pocas palabras, el rey espartano recurría a estratagemas y a acciones furtivas, y les hacía a sus rivales todo lo opuesto de lo que les hacía a sus amigos. ${ }^{55}$

Ciro el Joven

Este príncipe persa procuraba demostrarles su afecto a todos cuantos eran sus amigos y, a sus eficaces colaboradores, sabía como nadie colmarlos de atenciones. ${ }^{56}$ También honraba de manera muy especial a los valientes en la guerra. ${ }^{57}$ La gente lo apreciaba tanto que muchísimas personas deseaban confiarle sólo a él sus bienes, sus ciudades y sus cuerpos. ${ }^{58}$ Según Jenofonte, dicho Ciro fue el más amado entre los griegos y entre los bárbaros. ${ }^{59}$ Cuando el muchacho sucumbió en el enfrentamiento con su hermano Artajerjes II, perecieron combatiendo a su lado todos sus amigos y compañeros de mesa, lo cual constituye la máxima prueba

51 Ibid., II, 25 (traducción de Orlando Guntiñas Tuñón, Gredos). En II, 26-31, se proporcionan ejemplos concretos de su actuación como embajador.

${ }^{52}$ Ibid., IX, 7.

53 Ibid., I, 7.

${ }^{54}$ Ibid., VI, 4.

55 Ibid., VI, 5. Jenofonte agrega que, a pesar de que Agesilao trataba con mucha afabilidad a sus amigos, con sus adversarios era sumamente terrible (XI, 10), y siempre resguardaba las cosas de sus amigos, mientras diario procuraba aniquilar las de sus rivales (XI, 12).

$$
\begin{aligned}
& { }^{56} \text { An., I, 9, } 19 . \\
& { }^{57} \text { Ibid., I, 9, } 14 . \\
& { }^{58} \text { Ibid., I, 9, } 12 . \\
& { }^{59} \text { Ibid., I, 9, } 28 .
\end{aligned}
$$


de lo mucho que lo estimaban; ${ }^{60}$ pues lucharon a su lado mientras vivió y no dudaron ni un instante en morir defendiendo su cadáver. ${ }^{61}$

\section{Ciro el Viejo}

Éste es un personaje clave para comprender la propuesta de paideia que Jenofonte disemina a través de sus escritos, por eso es muy importante analizar con detenimiento la postura que el monarca adopta ante la amistad y la gratitud.

En primer lugar, Ciro el Viejo reconoce que la fidelidad no es una cualidad innata en el ser humano, por eso le recomienda a su hijo que se rodee de gente fiel ganándosela no con violencia, sino mediante la generosidad. ${ }^{62}$ Para él resulta indispensable que los subalternos vean a su jefe como amigo y no como adversario, de manera que no envidien sus éxitos ni lo traicionen en los fracasos $;{ }^{63}$ el que un líder se enoje al mismo tiempo con toda su gente es un grave error, ya que al infundir terror a muchos se atrae múltiples enemistades y, al enfurecerse con todos, es lógico que ellos se unan para conjurar contra él. ${ }^{64}$

De acuerdo con su padre Cambises, una de las principales tareas del dirigente es conseguir la buena disposición de sus hombres, para ello hay que comportarse exactamente igual que cuando se desea recibir el afecto de los amigos, en otras palabras, uno debe actuar como su protector. El padre de Ciro reconoce que todo esto es difícil:

tener la capacidad de beneficiar siempre a quienes uno desee beneficiar, mostrar que compartes su alegría si les sobreviene un éxito, que compartes su aflicción si les ocurre una desgracia, que tienes interés en ayudarles en las dificultades, que temes que vayan a cometer un error y que intentas tomar

\footnotetext{
${ }^{60}$ Ibid., I, 9, 30.

${ }^{61}$ Según Sócrates, habla muy bien de un gobernante el hecho de que su gente lo obedezca de buena gana y permanezca voluntariamente con él incluso en los momentos de sumo peligro, tal como lo hicieron los amigos de Ciro el Joven (Oec., IV, 19).

${ }^{62}$ Cyr., VIII, 7, 13.

${ }^{63}$ Ibid., II, 4, 10.

${ }^{64}$ Ibid., V, 5, 11. Ciro creía que los peligros comunes hacen que los soldados se lleven bien entre ellos y, en esta circunstancia, cesan las envidias, de modo que los hombres alaban y aprecian más a sus compañeros, porque los ven como colaboradores para alcanzar el bien común (III, 3, 10).
} 
medidas para que no lo cometan. Esta disposición es, sin duda, muy necesaria para prestarles ayuda. ${ }^{65}$

Ciro asevera que no hay nada más hermoso que socorrer a los amigos ${ }^{66}$ y a menudo sobresale por su generosidad. ${ }^{67}$ Se comportaba y se consideraba a sí mismo como un filántropo. ${ }^{68}$ Lejos de procurar enriquecerse, dicho soberano era más feliz dando que recibiendo, ${ }^{69}$ por eso utilizaba su riqueza para recompensar a los mejores y ayudar a los necesitados. ${ }^{70}$ Gracias a su conducta ejemplar, era tan amado por sus soldados, que de inmediato acuden a protegerlo al observar que es derribado de su caballo. ${ }^{71}$

En cuanto a la philía y a la gratitud que el ser humano siente hacia los dioses, desde que era joven, Ciro afirmaba que tiene más influencia tanto con las deidades como con los hombres, aquel que no las adula únicamente cuando se encuentra en dificultades, sino que se acuerda de ellas, sobre todo, cuando las cosas le salen a la perfección. Decía que, del mismo modo que se ocupa uno de las divinidades, hay que cuidar a los amigos. ${ }^{72}$

Este líder creía firmemente que el éxito no debe impedir que se disponga de tiempo libre para frecuentar a los amigos. ${ }^{73}$ Intentaba ganarse la amistad de sus hombres al atenderlos, al esforzarse por ellos, compartiendo sus alegrías y sus aflicciones, y cuando tuvo las posibilidades económicas, procuró compartir con ellos su riqueza, su comida y su bebida. ${ }^{74}$ De igual forma, ya como soberano, les daba un trato preferencial a sus amigos, al invitarlos a su mesa. ${ }^{75}$ En lugar de olvidarse de sus

65 Ibid., I, 6, 24-25 (traducción de Ana Vegas Sansalvador, Gredos).

${ }^{66}$ Ibid., I, 5, 12-13.

${ }^{67}$ Ibid., VIII, 4, 7.

${ }^{68}$ Ibid., VIII, 7, 25.

${ }^{69}$ Ibid., VIII, 4, 29, y en especial VIII, 4, 31.

70 Ibid., VIII, 4, 36.

${ }^{71}$ Ibid., VII, 1, 38.

72 Ibid., I, 6, 3. Padre e hijo están de acuerdo en que uno se dirige con más confianza a las divinidades, si siempre las tiene uno en mente y las considera sus amigas (I, $6,4)$.

${ }^{73}$ Ibid., VII, 5, 42.

${ }^{74}$ Ibid., VIII, 2, 2.

75 Ibid., VIII, 2, 3-4; VIII, 2, 7; VIII, 4, 1, y VIII, 4, 6. 
amistades cuando la fortuna y el éxito le sonreían, procuraba satisfacer las necesidades de sus allegados. ${ }^{76}$ Incluso en su lecho de muerte, el anciano Ciro les recomienda encarecidamente a sus hijos que beneficien a sus amistades. ${ }^{77}$ En suma, dicho personaje consideraba a los amigos como un tesoro, dignos y confiables guardianes tanto de su persona como de sus bienes. ${ }^{78}$

Para conducir a los demás hacia la "belleza y nobleza", él mismo se esforzaba por mostrarse frente a sus súbditos como el hombre más virtuoso del mundo. ${ }^{79}$ El soberano tenía la convicción de que él y sus hombres serían mejores al darles el mejor ejemplo posible a sus hijos; de manera que al no ver ni escuchar nada vergonzoso los niños no podrían ser malos, al vivir practicando cotidianamente la $\varkappa \alpha \lambda \mathrm{o} x \dot{\alpha} \gamma \alpha \theta \operatorname{có}{ }^{80}$ Ciro el Viejo sobresalía en todas las acciones nobles y también su gente, gracias a su constante entrenamiento; pues él mismo procuraba ser su modelo. ${ }^{81}$ Por último, este dignatario estaba seguro de que es propio del varón más honrado que, luego de dar muestras de su poderío, combata desde él por la $x \alpha \lambda \mathrm{\alpha} \dot{\alpha} \gamma \alpha \theta \operatorname{ci}^{8} .^{82}$

Es así como, a través de Ciro el Viejo, Jenofonte enfatiza que la amistad requiere de tiempo para cultivarla, ya que si no se comparten cosas comunes es fácil que dicho vínculo se pierda. Coincido con G. Herman en que toda relación amistosa conlleva dedicar cierta cantidad de tiempo a actividades realizadas con el amigo. Dado que la confianza se genera gracias a un proceso lento de interacción y a un gradual desarrollo de intimidad, la relación resultante se sostiene o se interrumpe debido a la constante interacción. ${ }^{83}$ Desde esta perspectiva, la amistad necesita fomentarse con tiempo y con acciones; pues implica afecto y cuidado mutuos.

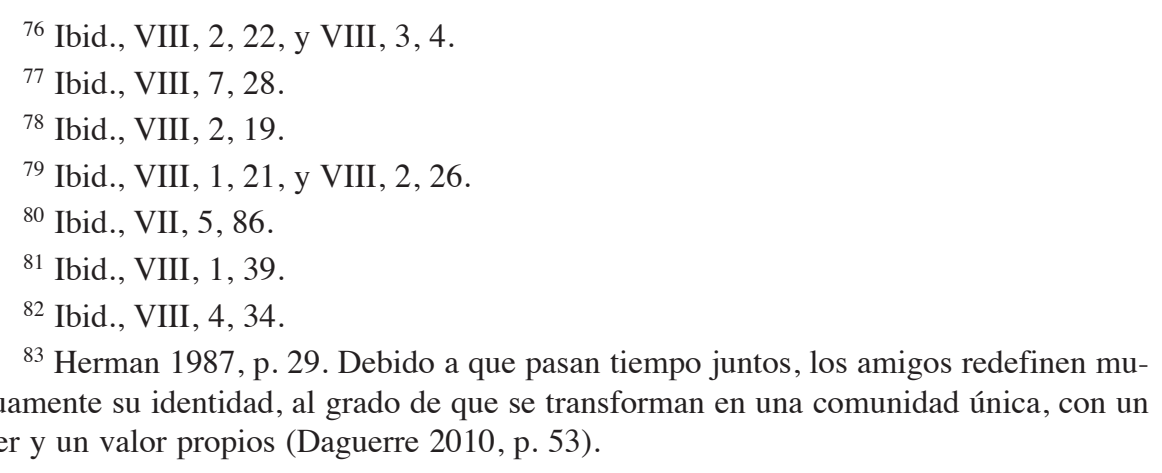


Hiparco ateniense

En cuanto asume el cargo de hiparco, es preciso que el jefe de la caballería ofrezca un sacrificio a las deidades, con el fin de que lo ayuden a pensar, hablar y actuar de un modo más grato para los dioses, más benévolo, más glorioso y más útil para él mismo, para sus amigos y para la polis. ${ }^{84}$

El Hiparco permanece en vela con tal de cuidar a sus hombres ${ }^{85}$ y comparte sus excedentes con quienes sobresalen por realizar algo provechoso ${ }^{86}$ Puesto que a él no lo guía la avaricia, no tiene ningún inconveniente en desprenderse de los bienes materiales; esto implica tanto su liberalidad como el reconocer públicamente a los soldados más destacados, su actitud generosa constituye una manera práctica de incentivarlos.

Intenta que sus subordinados tengan una disposición amistosa hacia él, ${ }^{87}$ lo cual equivale a fomentar la $\phi \mathbf{\imath} \lambda i_{\alpha}$ propiamente dicha y también la gratitud.

Este comandante es hábil para tender emboscadas contra el adversario, ${ }^{88}$ todo con el objetivo de sufrir las menores bajas posibles y capturar a los enemigos. La capacidad de tramar ardides y la actitud fraudulenta son

${ }^{84}$ Hipparch., I, 1.

${ }^{85}$ Ibid., VI, 3. El hiparco muestra su benevolencia hacia sus tropas con hechos reales, porque, en vez de descansar plácidamente, cuida de ellas.

${ }^{86}$ Ibid., VI, 3.

${ }^{87}$ Ibid., VI, 2. Lledó plantea que "las primeras formas de una amistad libre, más allá de la consanguinidad y la familia, tienen lugar en ese espacio donde van juntas la muerte y la vida. La defensa real del cuerpo y la defensa ideal de unos determinados valores, que la aristocracia guerrera había sublimado, dibujan el horizonte de referencia para nuevas formas de relación entre los hombres. Esas relaciones habían establecido una fórmula férrea, que expresaba el primer atisbo moral de las vinculaciones humanas: 'ama al amigo y odia al enemigo'. Un principio feroz como elemento de cultura y concordia, pero que, paradójicamente, ponía al descubierto la necesidad de la philía. En un pueblo agarrotado por guerras continuas, como fue el pueblo griego, esa teoría del comportamiento, donde entrechocaban los primeros balbuceos de la justicia y la injusticia, dejaba ver no sólo la dureza de la vida, sino la dificultad de defenderla. La discriminación y barbarie que encerraba tal comportamiento expresa, sin duda, una forma de reconocer la escasez que acosa a la existencia y confirma, efectivamente, la angustia de una naturaleza que tiene que luchar para vivir. Con ello, la naturaleza mostraba también su rostro de 'maestra de la vida', y enseñaba la salvaje lección de su pasión por defenderla" (Lledó Íñigo 2009, pp. 23-24).

${ }^{88}$ Hipparch., IV, 10, 12; V, 8, y VIII, 15, 20. 
imprescindibles para este oficial, ya que su deber primordial consiste en hacer el bien a los amigos y el mal a los adversarios. Se trata de una virtud específica del ámbito bélico.

Cuida que los soldados disciplinados tengan todo en abundancia, mientras los indisciplinados en todo sufran carencias. ${ }^{89}$

El hiparco tiene que esforzarse a cada instante por ser un hombre per-

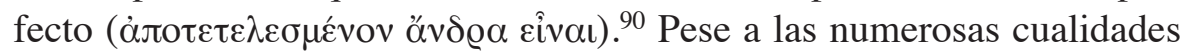
que debe reunir quien se desempeña como jefe de la caballería, la exigencia suprema estipulada por Jenofonte consiste en que tiene que ser un hombre perfecto, lo cual puede entenderse como $x \alpha \lambda$ ò $\varsigma \alpha \dot{\alpha} \gamma \alpha \theta$ ó $\varsigma$, porque la suma de todas las virtudes es sinónimo de perfección. Cabe señalar que, aunque en este texto el historiador no usa explícitamente dicho epíteto para el comandante, sí lo plantea a nivel conceptual. A mi juicio,

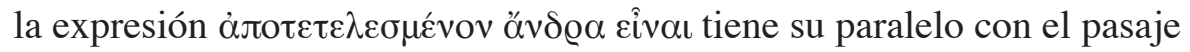
inicial del Agesilao. Es oportuno agregar que, aunque en el encomio

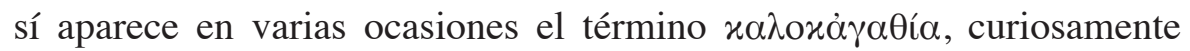

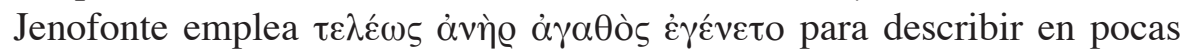
palabras la personalidad de su excepcional amigo espartano. ${ }^{91}$

\section{Iscómaco}

Entre los personajes atenienses a través de los cuales Jenofonte plantea su propuesta educativa destaca Iscómaco, quien en varias ocasiones es

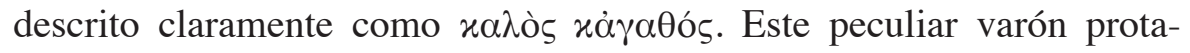
goniza el Económico. En dicho tratado el autor habla en concreto de la kalokagathía, concepto recurrente no sólo en este escrito, sino en toda su producción literaria; incluso a partir de dicho término el historiador desarrolla la personalidad de su agricultor ideal.

En sus plegarias, Iscómaco pide ante todo que las deidades le concedan la salud y la fuerza física, el aprecio de la ciudad y el afecto de sus amigos. ${ }^{92}$ En la vida cotidiana procura no perjudicar a nadie ${ }^{93}$ y sólo

${ }^{89}$ Ibid., I, 24. En cuanto a la implementación de premios, con el objetivo de que los caballeros entrenen más y se despierte en ellos la emulación, cf. I, 26.

${ }^{90}$ Ibid., VII, 4.

91 Ag., I, 1.

92 Oec., XI, 8.

93 Ibid., XI, 22. 
denuncia a aquellas personas que pretenden dañar a los demás ciudadanos. ${ }^{94}$

Hace buen uso de su fortuna, al honrar a los dioses con generosidad, socorrer a sus amigos y contribuir económicamente al embellecimiento de la polis $;{ }^{95}$ de igual forma, ayuda a todo el que puede, ${ }^{96}$ al ser generoso con los demás les enseña que sean leales. ${ }^{97}$

Cultiva la amistad. Aunque Iscómaco dedica mucho tiempo a cuidar su patrimonio, no por eso se olvida de sus amigos; entre otras cosas, se esfuerza por auxiliarlos en la medida de sus posibilidades. ${ }^{98}$

Se gana la obediencia voluntaria de sus hombres y fomenta el trato benévolo. Lejos de recurrir en primera instancia a la violencia para imponerse sobre su gente, reconoce que es propio de un buen líder realizar grandes acciones más con su fuerza de voluntad que con la fuerza bruta. ${ }^{99} \mathrm{~A}$ unos esclavos se los gana con comida y bebida, a otros con alabanzas; a los mejores les reparte mejores cosas (vestidos y zapatos) que a los malos, para que no se desmoralicen al recibir exactamente el mismo trato que quienes no cumplen con sus tareas. ${ }^{100}$

De igual modo, elogia y les concede honores a quienes se lo merecen, mientras a los negligentes les dice y les hace cosas que les duelan. ${ }^{101}$ Recompensa al que realiza bien su trabajo y castiga a los incumplidos. ${ }^{102}$ En síntesis, es un varón $x \alpha \lambda$ òs $x \alpha ̉ \gamma \alpha \theta o ́ s$.

Conviene aclarar que en el Económico el autor habla de manera expresa sobre la $\varkappa \alpha \lambda o x a ̉ \gamma \alpha \theta i ́ \alpha$, "suma de todas las virtudes". Para introducir

94 Idem.

95 Oec., XI, 9. Sócrates alaba la actitud del agricultor, pues la considera digna de un hombre rico y poderoso (XI, 10). Cabe observar que se espera que el kyrios administre su oikos respetando sus obligaciones internas, cumpliendo al mismo tiempo sus deberes para con la colectividad, mediante liturgias y obsequios a la ciudad (Ferrucci 2007, p.

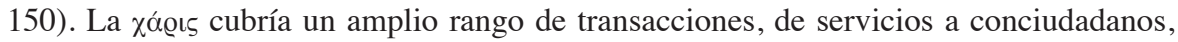
representada por la beneficencia pública (Konstan 1997, p. 82).

96 Oec., XI, 22.

${ }^{97}$ Ibid., XII, 5-7. Iscómaco afirma que la generosidad es el mejor instrumento para fomentar la lealtad (XII, 7).

${ }^{98}$ Ibid., XI, 9.

99 Ibid., XXI, 8.

100 Ibid., XIII, 10-11.

${ }^{101}$ Ibid., XII, 16.

102 Ibid., XII, 19. 
su diálogo con Iscómaco, Sócrates le dice a Critobulo que le va a contar el modo en que conoció a un hombre que le parecía que en realidad era

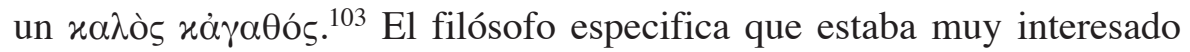
en conocer a alguno de los llamados $x \alpha \lambda$ oì $x \alpha \dot{\gamma} \gamma \alpha \theta$ oí, con la intención de saber qué hacía para recibir dicho calificativo. De esta forma, Sócrates define tal término: el sabio explica que, como inicialmente le concedió mayor importancia al adjetivo "bello", por lógica se acercaba a las personas de bella apariencia, mas al tratarlas se dio cuenta de que a veces esos individuos tenían un espíritu malvado, pues no siempre la belleza iba unida a la bondad. Ante su desengaño, decidió ya no hacer caso a la apariencia física, entonces buscó aproximarse a uno de los llamados "bellos y buenos", de acuerdo con la opinión de hombres y mujeres, ciudadanos y extranjeros, quienes se expresaban así de Iscómaco. Por ese motivo se propuso establecer contacto con él. ${ }^{104}$ Tan pronto como el hijo de Sofronisco se encuentra con el famoso agricultor, le pide una y otra vez que le explique qué hace para gozar de tan buena reputación, para ser un $x \alpha \lambda$ òs $x \alpha \dot{\alpha} \alpha \theta$ ós; ya que él desea aprender según su capacidad se lo permita. ${ }^{105}$ El caballero acepta con tal de que Sócrates le diga sinceramente si se equivoca en algo, a lo que el sabio replica con un dejo de ironía que cómo un hombre como él podría corregir a un varón "bello y bueno", él que es calificado como charlatán, de estar siempre en las nubes y de ser pobre. ${ }^{106}$ Es pertinente observar que, al aludir a su pobreza, de inmediato el maestro de Jenofonte refiere la anécdota del caballo de

${ }^{103}$ Ibid., VI, 12. En VII, 2 y 3, Sócrates e Iscómaco mencionan el término $x \alpha \lambda$ òs

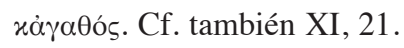

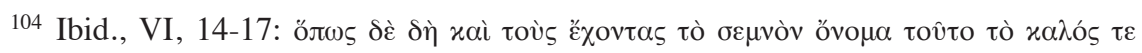

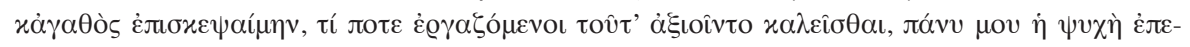

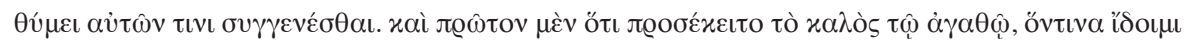

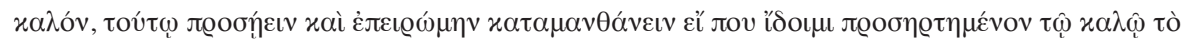

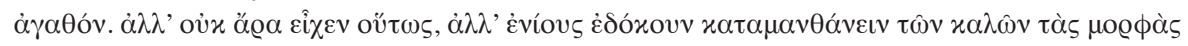

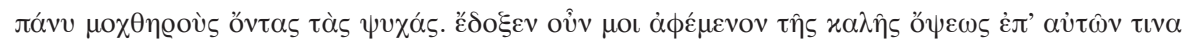

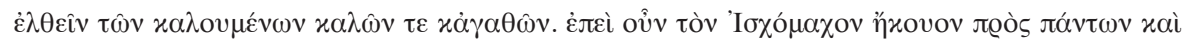

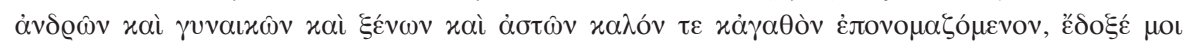

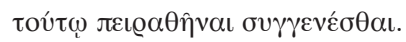

105 Ibid., XI, 1. En XI, 11, Sócrates nuevamente le pide al agricultor que le cuente con lujo de detalle qué hace, y dice expresamente que deje para el último lo concerniente a la manera de hacer dinero, a todas luces este punto es el que menos le interesa, ya que ante todo le importa practicar la virtud.

106 Ibid., XI, 3. 
Nicias, y afirma que sintió un gran alivio al oír que incluso a un caballo pobre se le permite que sea bueno con tal de que tenga un alma noble. ${ }^{107}$ Con base en esto, es factible deducir que el filósofo y el propio Jenofonte están convencidos de que la pobreza no constituye un impedimento para aspirar a la máxima virtud; porque también el humilde maestro del

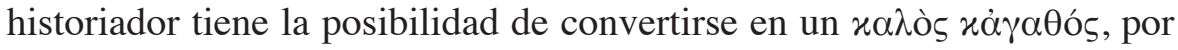
eso quiere aprender directamente de Iscómaco. ${ }^{108}$

\section{Sócrates}

El protagonista a través del cual Jenofonte manifiesta con mayor detalle su postura en torno a la amistad y la gratitud es Sócrates, quien valoraba mucho tener buenos amigos. ${ }^{109}$ Consideraba a la philía como el don más preciado; por ello, decía que, en vez de verla con desdén, hay que cultivarla. ${ }^{110}$ Para él, la principal ganancia es conseguir un buen amigo; ${ }^{111}$ mientras las enemistades y los peligros son característicos de la violencia. ${ }^{112}$ Creía firmemente que nada se equipara a la obtención de un buen amigo: ningún caballo ni ninguna pareja de bueyes es tan útil como él; nadie es tan leal y constante; ninguna otra posesión es tan benéfica en todos los aspectos. ${ }^{113}$ En su encomio de la amistad, señala lo siguiente:

el buen amigo está siempre en su sitio dispuesto a proveer a su amigo en todo lo que le falte, ya sea para la gestión de sus asuntos privados o de

107 Ibid., XI, 5.

${ }^{108}$ Ibid., XI, 6.

${ }^{109}$ Mem., I, 6, 14; II, 4; II, 5; II, 6; II, 9 y 10. Agradezco a Enrique Hülsz Piccone la observación de que Jenofonte maneja muchos argumentos que coinciden con el Lisis de Platón, diálogo dedicado a la philía.

${ }^{110}$ Ibid., I, 2, 7-8 y 14, así como II, 4, 5-7. Los filósofos antiguos consideraron a la amistad como una virtud fundamental, no nada más por el lugar que ocupa en la vida moral del ser virtuoso, sino también por la función tan importante que ejerce en la constitución de las ciudades, en la enseñanza de la filosofía e incluso en la explicación de la armonía del universo (Zamora Calvo 2009, p. 7).

${ }^{111}$ Mem., I, 2, 7.

112 Ibid., I, 2, 10.

${ }^{113}$ Ibid., II, 4, 5-6. Ver también I, 2, 7, y Oec., I, 14. El filósofo sostiene que los amigos son más agradables que la comida, el vino y las mujeres (Mem., I, 5, 4). En lugar de preferir a los caballos finos, a los perros o a las aves, Sócrates se inclinaba más por los buenos amigos (ibid., I, 6, 14). 
las actividades públicas, y si hay que prestar ayuda a alguien, colabora, si el miedo le conturba, acude en su ayuda, unas veces contribuyendo a los gastos, otras trabajando con él, otras ayudando a persuadir u obligando a la fuerza, mostrando la mayor alegría en las buenas situaciones y el apoyo más grande en las desgracias. Todo lo que a un hombre le ayudan sus manos y ven los ojos por él, oyen por él sus oídos o consiguen sus pies al caminar, todo lo supera el amigo con su ayuda. A menudo, lo que alguien no consiguió terminar por sí mismo, o no lo llegó a ver, o no lo oyó, o no lo acabó de recorrer, el amigo lo realiza por su amigo. Sin embargo, algunos intentan cultivar árboles por sus frutos, pero cuando se trata de la posesión más fructífera, que es un amigo, la mayoría la atienden con pereza y desmayo. ${ }^{114}$

El sabio pensaba que el placer más grande consiste en llegar a ser una mejor persona y tener excelentes amigos. ${ }^{115}$ Decía que quienes luchan voluntariamente por conseguir buenas amistades, por derrotar a sus enemigos, o por llegar a ser fuertes de cuerpo y alma para dirigir bien sus casas, ser útiles a sus amigos y servir a la patria, disfrutan sus esfuerzos, están satisfechos de sí mismos y son objeto de alabanza y envidia. ${ }^{116}$ Sócrates confiaba en que los discípulos que seguían sus consejos serían para él, y entre ellos, excelentes amigos para toda la vida. ${ }^{117}$ Sostenía que, aunque uno sea prudente, hay que evitar convivir con individuos perversos, en vez de eso conviene frecuentar a las personas buenas, pues así se ejercita uno mismo en la virtud. ${ }^{118}$

En primer lugar procuraba elevar moralmente a sus amistades, ${ }^{119}$ pero no sólo le interesaba contar con buenos amigos, sino incluso procuraba presentarlos entre sí para que juntos se esforzaran por llegar a ser vir-

${ }^{114}$ Mem., II, 4, 6-7 (traducción de Juan Zaragoza, Gredos). Mediante esta lista el filósofo destaca las razones prácticas para adquirir amigos, no para que uno procure tener más amistades debido al beneficio que uno obtiene, sino para reprocharle a uno que no sea útil para sus amigos (Konstan 1997, p. 80).

115 Mem., I, 6, 9.

116 Ibid., II, 1, 18-19. Los amigos que practican el bien lado a lado, evocan irresistiblemente la imagen de los héroes en el combate, quienes practican la emulación y se exaltan de su semejanza. Aristóteles e incluso "Jenofonte manifiestan una ideología militar, identitaria y fusional" (Temple 2003, p. 173).

${ }^{117}$ Mem., I, 2, 8.

118 Ibid., I, 2, 20.

${ }^{119}$ Sócrates afirma que ésta es la primera tarea del gobernante (Mem., I, 2, 3). 
tuosos. ${ }^{120}$ Dentro de sus reflexiones sobresale que para conseguir amigos buenos, ha de ser bueno también uno mismo. ${ }^{121}$ Asevera que el hombre que se adelanta en hacer daño a sus enemigos y bien a sus amigos es tenido en altísima estima. ${ }^{122}$ En suma, para él, sin amistad ninguna relación vale la pena. ${ }^{123}$

De acuerdo con Sócrates, quien descubre a un ser de buen temperamento, le enseña lo bueno que sabe y lo convierte en un buen amigo, es un hombre $x \alpha \lambda$ òs $x a \dot{\gamma} \alpha \theta$ ó ${ }^{124}$ Así se comportaba él, pues procuraba enseñarles a sus amistades cuanto sabía y los ponía en contacto entre ellos, a fin de que practicaran la virtud, y junto con sus amigos compartían las lecciones de los sabios antiguos. ${ }^{125}$

Aunque nunca se asumió a sí mismo como maestro, con su ejemplo y con su congruencia fomentó en sus discípulos la esperanza de que, si lo imitaban, llegarían a ser tan virtuosos como él. ${ }^{126}$ Este singular filósofo no cobraba, debido a su firme convicción de que así aseguraba

${ }^{120}$ Ibid., I, 6, 14; II, 4-6. La honestidad es muy importante porque ayuda a distinguir a los verdaderos amigos, la gente necesita la crítica constructiva para reconocer sus faltas (Konstan 1997, p. 15).

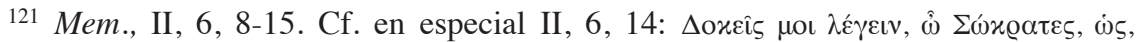

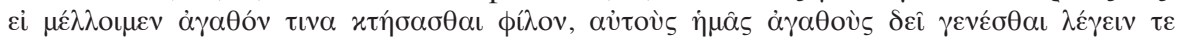

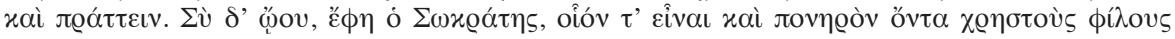
xтү் $\alpha \sigma \theta \alpha$; La importancia de conocerse a sí mismo radica en que el individuo virtuoso con frecuencia posee un conocimiento más profundo de él mismo y de aquellos con quienes ha pasado más tiempo de modo íntimo, y por lo común se encuentra en mejor posición para cultivar y promover los fines que valora genéricamente, en su propia persona y en la de sus allegados, que en la persona de aquellos con quienes tiene relaciones menos cercanas (Daguerre 2010, p. 50).

${ }^{122}$ Mem., II, 3, 14.

${ }^{123}$ Symp., VIII, 13.

${ }^{124}$ Mem., I, 6, 13.

${ }^{125}$ Ibid., I, 6, 14. Para Sócrates, la amistad tiene un objetivo noble y educativo, sin que implique comercio carnal (Fernández Caraballo 2013, p. 68). Además, la unión

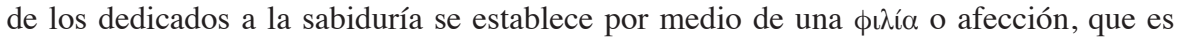
la filosofía, en cuanto vínculo hacia la Sabiduría y entre los interesados en ella (ibid., p. 69).

${ }^{126}$ Mem., I, 2, 3. Acerca de que el sabio ayudaba a sus discípulos, a veces por medio de acciones que mostraban su forma de ser y otras dialogando con ellos, cf. la opinión

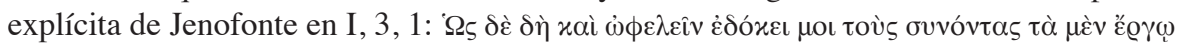

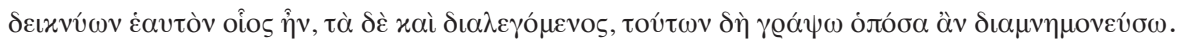
Sobre esto mismo, I, 5, 6, y IV, 5, 1 . 
su libertad y a que creía que su mayor ganancia era obtener un buen amigo. ${ }^{127}$

Desde el punto de vista de Jenofonte, su maestro se preocupaba más por enseñarles a sus acompañantes la virtud y el buen juicio antes que la elocuencia o la administración; para evitar así que incurrieran en la injusticia y en malas acciones. ${ }^{128}$

Jamás promovió una guerra, ni una rebelión, una traición o algún otro perjuicio; nunca robó ni ocasionó daño a nadie, ni cometió crimen alguno. ${ }^{129}$ No dio falso testimonio, no delató o provocó discordias entre amigos o en la polis, tampoco actuó injustamente. ${ }^{130}$ Nunca le hizo daño o indujo al mal a nadie; por el contrario, en todo momento procuró que sus acompañantes fueran mejores. ${ }^{131}$ Siempre era provechoso estar con él, incluso evocar su recuerdo era útil para recibir lecciones, ya fuera que hablara en serio o que bromeara. ${ }^{132}$ Fue el colaborador más útil en la búsqueda por alcanzar la virtud; no sólo hacía que sus acompañantes

${ }^{127}$ Ibid., I, 2, 6-7. En torno a que no cobraba, cf. también I, 2, 59-60, y Apol., 16. Al respecto, Domingo Plácido sostiene que "El sistema socrático enuncia así las aspiraciones de la nueva sociedad tendente [...] a alejarse de la alternativa del misthós como renta a través de la recuperación de las relaciones arcaicas entre evergetismo y cháris. De este modo, puede evitarse tanto la caída en la esclavitud como la práctica del misthós creadora de relaciones esclavistas. Con ello se crea el entramado ideológico que apoya las relaciones clientelares en criterios sublimados por la amistad y el agradecimiento" (Plácido Suárez 2012, pp. 43-44). Para José Solana, "el intento socrático de combatir a los sofistas consiste en rescatar la educación del espacio democrático y laboral para integrarla de nuevo en un marco más estrecho, el marco de la amistad y de la hetería, el espacio del ocio, donde el maestro no contrae ningún compromiso con el discípulo. Sócrates explica su modelo como un modelo de libertad, en tanto sus adversarios, los sofistas, serían esclavos del compromiso que implica su contrato con el discípulo. La libertad socrática es así elitismo, es decir, libertad de aceptar o rechazar a sus discípulos" (Solana Dueso 2009, p. 37).

${ }^{128}$ Mem., IV, 3, 1. A partir de ciertos pasajes de Memorables, es factible observar que la ambición política conduce a la filosofía política; pues el hombre ambicioso está interesado no sólo, o básicamente, en el bienestar de su comunidad política, sino también y específicamente le preocupa su propia excelencia o virtud (Lorch 2010, pp. 189-211).

\footnotetext{
${ }^{129}$ Mem., I, 2, 63.

${ }^{130}$ Ibid., IV, 4, 11.

${ }^{131}$ Ibid., IV, 8, 10.
}

132 Ibid., IV, 1, 1. Al entablar amistad con una persona virtuosa uno se siente estimulado a aumentar su dedicación a fines valiosos, los propios de un individuo virtuoso (Herman 1987, p. 29). 
aceptaran sus errores, sino que los encauzaba hacia la virtud y la "belleza

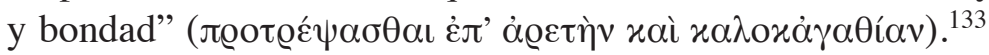

Sobre la $x \alpha \lambda$ ox $\alpha \gamma \alpha \theta i ́ \alpha$, de acuerdo con el historiador todos los maestros les muestran a sus discípulos de qué modo hacen lo que enseñan y los guían por medio de la palabra. ${ }^{134}$ Es oportuno recordar que, gracias a su ejemplo, Sócrates alejó a muchos jóvenes de los vicios, les hizo anhelar la virtud y los animó a cuidar de sí mismos; para que al imitarlo

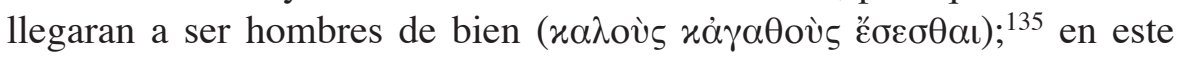

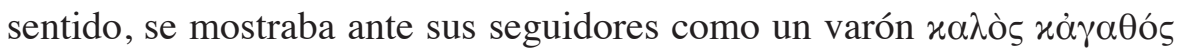
y como tal conversaba hermosamente sobre la virtud y otras cualidades humanas. Acerca de lo que Sócrates pensaba que debía saber un hombre "bello y bueno", él mismo se preocupaba por enseñar lo que sabía, cuando no dominaba algún tema los mandaba con algún experto. ${ }^{136} \mathrm{El}$ sabio afirmaba que la $x \alpha \lambda$ ox $\alpha \gamma \alpha \theta i ́ \alpha$ es el mejor perfume, y recomendaba que si se quiere ser virtuoso hay que frecuentar a quien sea capaz de hacerle practicar a uno la virtud. ${ }^{137}$ Según el filósofo, las acciones son más convincentes que las palabras; ${ }^{138}$ en torno a esto, Jenofonte asegura que, a través de su propio ejemplo, Sócrates volvía a sus compañeros más piadosos, virtuosos y prudentes. ${ }^{139}$ En otro pasaje añade que su

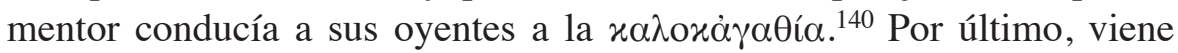
al caso mencionar que también en el Banquete ${ }^{141}$ y en la Ciropedia $^{142}$ el

${ }^{133}$ Mem., IV, 8, 11.

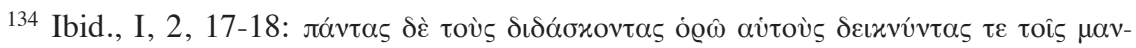

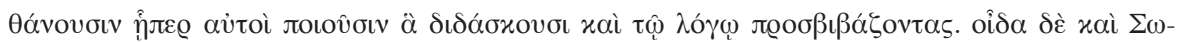

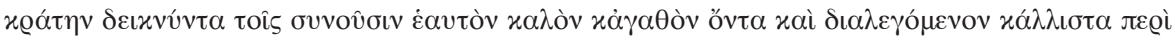

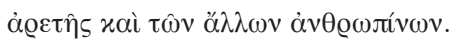

135 Ibid., I, 2, 2 y 3. En I, 3, 1, se menciona que en ocasiones el filósofo ayudaba a sus seguidores con actos que demostraban su manera de ser y otras conversando con ellos. Sobre esto mismo, I, 5, 6, y IV, 5, 1.

${ }^{136}$ Ibid., IV, 7, 1, y Oec., II, 15-16, por sólo citar algunos ejemplos.

137 Symp., II, 4-5.

${ }^{138}$ Ibid., IV, 4, 10.

${ }^{139}$ Ibid., IV, 3, 18.

${ }^{140}$ Ibid., I, 6, 14.

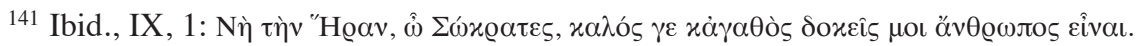

142 Jenofonte no nombra al filósofo, pero lo evoca cuando Ciro el Viejo le pregunta al joven Tigranes por el varón excepcional a quien el muchacho solía frecuentar, y éste con-

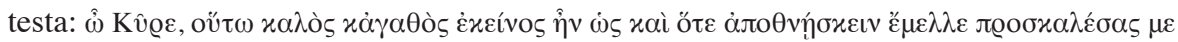

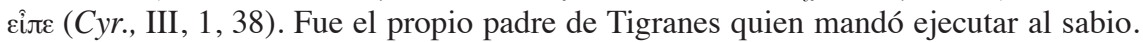


jefe de los Diez Mil define al hijo de Sofronisco como un hombre xaגòs

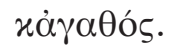

Concretamente acerca de la utilidad de los amigos, Sócrates veía que, aunque la mayoría de sus conciudadanos afirmaban que el bien más preciado de todos es tener un amigo bueno y leal, en la práctica se olvidaban de esto y se afanaban mucho más por adquirir y conservar sus bienes materiales. ${ }^{143}$ Le daban tan poca importancia al fomento de la amistad, que no se esforzaban por obtener nuevos amigos, ni siquiera les interesaba conservar a los que ya tenían. ${ }^{144}$ Ante la disyuntiva de prestarle auxilio a un esclavo o a algún amigo enfermos, varias personas elegían velar por el primero; incluso, sufrían más por la muerte de un sirviente que por la de un amigo, pues el fallecimiento de aquél implicaba para ellos una gran pérdida económica, mientras el deceso del amigo no les afectaba tanto. ${ }^{145}$ Desde el punto de vista de Sócrates, contar con un colaborador espontáneo, leal, constante, no sólo dispuesto a acatar órdenes, sino a procurar voluntariamente ser útil, a prevenir y prever, es igual a tener muchos esclavos. ${ }^{146}$ Con base en esto, lamenta que muchos estén al pendiente de todas y cada una de sus posesiones, mientras descuidan a sus amistades principalmente cuando más los necesitan. Esta clase de individuos saben con precisión cuántas propiedades poseen, pero ignoran el número exacto de amistades con las que en verdad cuentan. ${ }^{147}$

${ }^{143}$ Mem., II, 4, 1-2. El filósofo sostiene que es mucho mejor poseer un rebaño de amistades que uno de ovejas, vacas o cabras (III, 11, 5). En III, 11, 6-7, Sócrates le aconseja a Teodota que, al igual que las arañas, teja una finísima red para atrapar amigos, ya que es la cacería más valiosa de todas.

144 Ibid., II, 4, 2. Según el historiador, su maestro recomendaba dedicarse a la agricultura, pues dicha actividad le permite a uno tener tiempo libre para los amigos y la ciudad (Oec., VI, 9).

145 Mem., II, 4, 3.

146 Ibid., II, 7, 3. De acuerdo con Domingo Plácido, "se trata de la situación crítica creada después de la guerra, en la que el libre necesitado puede encontrar cierta salida a sus problemas en la dependencia del dominante protector" (2012, p. 44).

${ }^{147}$ Mem., II, 4, 4. Sócrates está en contra de que se abandone a su suerte a un amigo que tiene problemas financieros (II, 5, 1). Viene al caso puntualizar que "Khreia en este pasaje no se refiere a calcular la explotación de los amigos, no implica utilidad, equivale más a 'cuidado'. Así pues, khrêsimon significaría 'útil' y khrêstos 'excelente', en el sentido moral, subrayando la dimensión ética de la amistad, en oposición al valor utilitario de los bienes materiales [...]. En pocas palabras, es una lección sobre los deberes para con los amigos, no un balance práctico" (Konstan 1997, p. 80). 
El Sócrates jenofóntico retoma la comparación entre el valor monetario de los bienes materiales y el de las amistades, con el objetivo de que cada quien se examine a sí mismo y vea si en realidad es digno de tener amigos y, sobre todo, buenos amigos. ${ }^{148}$ Enfatiza que así como los esclavos tienen un precio, también las amistades; según la calidad del amigo su cotización es más alta. ${ }^{149}$ Mediante esta analogía el sabio sugiere que uno mismo analice qué tan valioso resulta para sus amistades, y nos invita a esforzarnos por ser amigos de excelente calidad, para que nuestros allegados no nos abandonen seducidos por la avaricia; ${ }^{150}$ porque a los seres buenos no se les vende si son esclavos, ni se les abandona si son amigos. ${ }^{151} \mathrm{Al}$ aludir al ambiente caótico que prevalecía en Atenas, secuela de la postguerra, Sócrates advierte que es el momento oportuno para comprar buenas amistades a buen precio. ${ }^{152}$

Ahora bien, ¿qué clase de amigos vale la pena conseguir? Hay que inclinarse hacia personas que no se dejan dominar por las pasiones, hospitalarias, afables, dispuestas a devolver los favores que reciben, útiles a quien se relaciona con ellas. ${ }^{153}$ Quienes tratan bien a los demás son buenos amigos. ${ }^{154}$ También hay que procurar la amistad de quien respeta la ley y es justo, ya que esta clase de individuo es digno de confianza para depositar su dinero, un hijo o una hija; éste devuelve los favores; un

${ }^{148}$ Mem., II, 5, 1.

149 Ibid., II, 5, 3.

${ }^{150}$ Ibid., II, 5, 4. Si uno es un amigo muy valioso como persona, difícilmente podrán traicionarlo a cambio de dinero.

${ }^{151}$ Ibid., II, 5, 5.

152 Ibid., II, 10, 4. Se subraya la trascendencia de la philía en el socratismo; en los días aciagos que vinieron tras la Guerra del Peloponeso, el filósofo ayuda a sus amigos para que aprovechen sus propios recursos (Plácido Suárez 2012, p. 42). La amistad también puede ser concebida como solidaridad mutua entre individuos que se organizan en función de una serie de intereses de diversa índole ya sea económica, social o religiosa (Enjuto Sánchez 2009, p. 93). La verdadera amistad se caracteriza por la buena disposición para auxiliar a los amigos que se encuentran en serios problemas, por eso la philía no depende sólo de los sentimientos e intenciones, sino también de los hechos: lo que cuenta son los actos más que las palabras (Konstan 1997, p. 56). Tanto los escritores griegos como los romanos reconocieron la utilidad de los amigos, entre otras cosas recomiendan la amistad como una fuente de seguridad y socorro (cf. ibid., p. 13, y Santiago Martínez 2007).

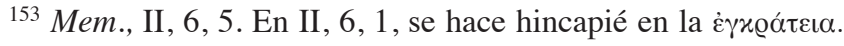

${ }^{154}$ Ibid., IV, 4, 24. 
hombre que obedece la ley, merece la confianza de toda la polis; ya que es justo con sus padres, con sus familiares y amigos, con los ciudadanos y los extranjeros; cumple su palabra y sus juramentos, así como los pactos con los enemigos; es la persona más agradecida; la mayoría de la gente busca ser su amiga, en vez de enemistarse y pelear con él. ${ }^{155}$

¿Qué tipo de seres humanos no son buenos amigos? Hay que evitar a los que ceden ante la gula, la sed, la lujuria, el sueño o la pereza; pues éstos no son capaces de cumplir con sus propias obligaciones ni con las de su amigo. ${ }^{156}$ También hay que alejarse del despilfarrador, porque siempre necesita dinero, no paga y se molesta si no se le ayuda. ${ }^{157}$ Así mismo, hay que descartar al que es bueno para hacer negocios, pero como desea más riqueza le agrada recibir pero no le gusta dar; y a quien se pasa todo el tiempo pensando cómo ganar más dinero, al sedicioso, y a quien está habituado a recibir sin dar nada a cambio. ${ }^{158}$

Sócrates aconseja observar muy bien la conducta del candidato a amigo, para ver si en verdad merece nuestra amistad: si trata bien a sus amistades anteriores, es muy probable que haga lo mismo con sus nuevos amigos, incluso las deidades mandan señales para indicar si conviene su amistad. ${ }^{159}$ Una vez que el amigo potencial aprueba el examen, es preciso ganarse su amistad; para lograrlo, es necesario no acosarlo, ni ser violentos con él, pues no se puede ser amigo de alguien en contra de su voluntad. ${ }^{160}$ Para conseguir la amistad de alguien es mejor conducirse con naturalidad y corrección, con buenas maneras y trato complaciente; porque la violencia no permite obtener ni retener a un amigo. ${ }^{161} \mathrm{El}$ filósofo se pronunciaba a favor del trato amable, por ello les recalcaba

155 Ibid., IV, 4, 17. Quien viola la ley, además de sufrir un castigo, es abandonado por sus amigos (IV, 4, 24).

156 Ibid., II, 6, 1.

${ }^{157}$ Ibid., II, 6, 2.

158 Ibid., II, 6, 3. Aparte de interesada, es una persona malagradecida aquella que no corresponde al buen trato que le dan los demás (IV, 4, 24). Por lo general, los griegos consideraron que si alguien maltrataba a sus amigos o no los ayudaba en una emergencia, merecía perder su amistad. En este sentido, la philía conllevaba obligaciones éticas, que con frecuencia, y comprensiblemente, se ilustraban con términos económicos (Konstan 1997, p. 80).
${ }^{159}$ Mem., II, 6, 6-8.
160 Ibid., II, 6, 9.
${ }^{161}$ Ibid., III, 11, 11. 
a sus alumnos que sólo mediante regalos se puede ganar uno a los hombres ruines, mientras a los varones $x \alpha \lambda$ oì $x \alpha \hat{\gamma} \gamma \alpha \theta$ oí basta con tratarlos de manera amigable. ${ }^{162}$ Aunque hay distintos hechizos para conseguir la amistad de alguien, ${ }^{163}$ lo más recomendable es actuar como Pericles y Temístocles, quienes con palabras y con actos se ganaron el afecto de la polis. ${ }^{164}$ De manera que, si uno desea obtener buenos amigos, es esencial que uno mismo sea bueno y lo demuestre con palabras y con hechos; porque no es posible que una persona malvada tenga amigos buenos. ${ }^{165}$ En otras palabras, primero hay que esforzarse por ser una buena persona, una vez que se logre esto, conviene intentar atrapar a los hombres "bellos y buenos". ${ }^{166}$ Ganarse la amistad de los demás es más sencillo si uno demuestra con actos que está al pendiente de sus amigos y que lo que más le agrada es convivir con buenos amigos, que se enorgullece uno por las bellas acciones de ellos y las siente como propias, que no le molesta trabajar para que sus amistades prosperen, pues está convencido de que la virtud del ser humano radica en derrotar a los amigos haciendo el bien y a los rivales haciendo daño. ${ }^{167}$

La gente malvada es incapaz de ser amiga entre sí; por eso los malagradecidos, los negligentes, los ambiciosos, los desleales y quienes sucumben ante las pasiones ni siquiera son buenos amigos entre ellos, porque han nacido para odiarse..$^{168}$

Sócrates reconoce que una parte del ser humano es amistosa y la otra belicosa; sin embargo, la фı $\lambda$ ía supera los obstáculos y une a los hombres $x \alpha \lambda$ ol̀ $x \dot{\alpha} \gamma \alpha \theta$ oí, ya que a causa de la virtud: se conforman con una riqueza moderada, en lugar de adueñarse de todo a través de la guerra; pese a estar hambrientos y sedientos, son capaces de compartir sus alimentos y sus bebidas; aunque gustan de los placeres de Afrodita, son capaces de abstenerse con tal de no ofender a los demás; evitan la codicia y se

162 Ibid., II, 3, 16.

${ }^{163}$ Ibid., II, 6, 10-12, donde Sócrates alude a encantamientos, drogas, al canto de las Sirenas y a la adulación.

${ }^{164}$ Ibid., II, 6, 13. El filósofo señalaba que con los amigos hay que ser lo más sinceros posible (IV, 2, 16).

165 Ibid., II, 6, 14. En II, 6, 16, Sócrates retoma la idea de que no es factible que un hombre malvado logre adquirir amigos virtuosos.

166 Ibid., II, 6, 28.

167 Ibid., II, 6, 35 .

168 Ibid., II, 6, 19. 
prestan ayuda mutua; solucionan sus diferencias sin faltarse al respeto y de común acuerdo; no permiten que la ira los impulse a hacer algo de lo que más tarde se arrepientan; lejos de fomentar la envidia, comparten sus bienes con los amigos y en ocasiones consideran como propias las fortunas de sus amistades. ${ }^{169}$ De manera que cuando un hombre "bello y bueno" ocupa alguna magistratura se esfuerza por ayudar a sus amigos y por hacerle bien a su patria, tomando como colaboradores a otros hombres "bellos y buenos". ${ }^{170}$ El sabio aclara que cuando se ejerce el poder es provechoso conseguir la amistad de los individuos $x \alpha \lambda$ ol̀ $x \dot{\alpha} \gamma \alpha \theta$ oí y utilizarlos como ayudantes, es preferible que sean colaboradores y no rivales. Mediante el buen trato hay que ganarse a la gente que desea aliarse con uno; ya que conviene más tratar bien a los mejores, que son pocos, a ser amables con los malvados, que son la mayoría, pues este tipo de hombres requieren muchos más favores que los virtuosos. ${ }^{171}$

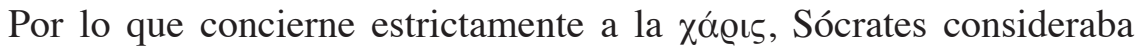
que la gratitud es una de las principales características del hombre virtuoso. ${ }^{172}$ En esto tambien ponía el ejemplo, puesto que a todas luces el

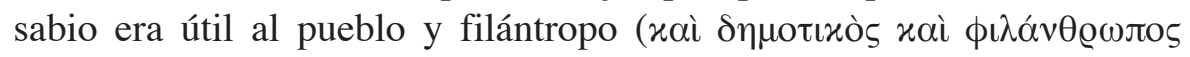
Ø̋v), y compartía sus bienes con generosidad. ${ }^{173}$ Gracias a su estilo de vida austero, estaba presto a auxiliar a sus amigos y a la ciudad. ${ }^{174}$

A su juicio, el individuo $x \alpha \lambda$ òs $x \alpha \dot{\gamma} \alpha \theta$ ó $\varsigma$ siente mayor gratitud hacia quien le hace el mayor favor. ${ }^{175}$ De acuerdo con Sócrates, la amistad es un gran beneficio. ${ }^{176}$ Subraya que las deidades no le conceden nada a los seres humanos sin esfuerzo ni cuidado; de modo que, si se desea que los dioses le sean favorables, hay que venerarlos; si se quiere tener amigos que lo aprecien a uno, hay que hacerles favores, y si se anhela

${ }^{169}$ Ibid., II, 6, 22-23.

${ }^{170}$ Ibid., II, 6, 25.

${ }^{171}$ Ibid., II, 6, 26-27.

${ }^{172}$ Cf. en específico Mem., II, 10, 3. Xó@ıs podía abarcar desde su sentido primario "alegría" o "placer" y "gratificación", hasta "favor"; de manera que puede ser tanto lo que se da como lo que se regresa (Mitchell 1997, pp. 18-19). En sentido lato, dicho vocablo tiene la acepción de "gratitud" (Konstan 1997, p. 81).

${ }^{173}$ Mem., I, 2, 60. Siempre fue un hombre generoso con sus bienes, y al contribuir a que sus discípulos se perfeccionaran les hizo el mayor favor de todos (idem).

\footnotetext{
174 Ibid., I, 6, 9.

175 Ibid., I, 2, 7.

176 Ibid., I, 6, 14.
} 
que la polis lo honre a uno, hay que servirle. ${ }^{177}$ Por eso, para el filósofo es digno de alabanza aquel que se apresura a hacerle mal a los enemigos y corre a ayudar a los amigos. ${ }^{178}$

Por su parte, procuraba subsanar la ignorancia de sus allegados con consejos, pero cuando los veía inmersos en problemas económicos, los conminaba a prestarse auxilio mutuo según los recursos financieros de cada quien. ${ }^{179}$ Recomendaba que, cuando uno se sienta afligido, comparta sus preocupaciones con sus amigos, pues quizá ellos pueden socorrernos de algún modo. ${ }^{180}$

Así como el sabio se empeñaba en fomentar la amistad y la gratitud, así mismo trataba de erradicar la ingratitud (ả $\alpha \varrho \iota \sigma \tau i ́ \alpha)$, pues para él es equivalente a la injusticia; ${ }^{181}$ por eso, quien después de recibir un favor no corresponde de la misma forma, es injusto. ${ }^{182}$ Sócrates afirmaba de manera categórica que los individuos que no son útiles ni con actos ni con palabras, que no sirven ni siquiera para ayudar al ejército, a la polis y al pueblo, que además de todo son soberbios, deben ser castigados, sin importar que sean muy adinerados. ${ }^{183}$

Para él, una persona malagradecida es aquella que, luego de que la tratan bien, no devuelve dicho favor; esta clase de individuo es al mismo tiempo injusto. ${ }^{184}$ Por lo tanto es injusto ser malagradecido con los amigos. ${ }^{185}$ Es más, de acuerdo con Sócrates, una persona ingrata no puede ser un buen amigo, y vale la pena agregar que tampoco será un buen ciudadano. ${ }^{186}$

Al recordar a su maestro, Jenofonte hace hincapié en que varios jóvenes lo buscaban con el único fin de convertirse en hombres "bellos y buenos" y ser capaces de tener una buena relación con su familia, con

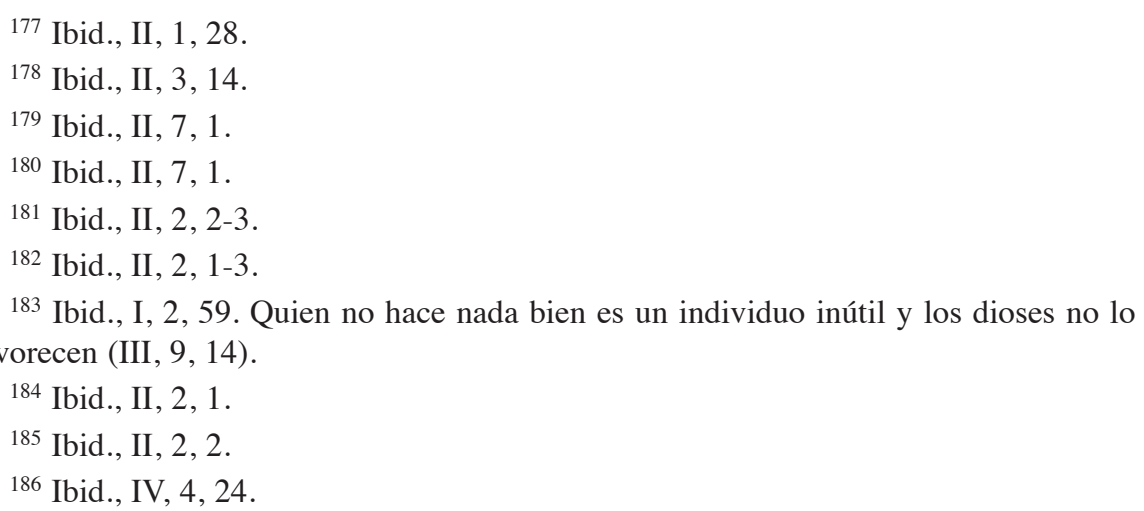


sus parientes y amigos, con la ciudad y sus compatriotas. ${ }^{187}$ Conforme a lo anterior, la philía no sólo entrañaba un vínculo estrecho con alguien ajeno al hogar, sino que también podía abarcar las relaciones filiales, esto es, familiares; de ahí que el filósofo se preocupe por inculcar el cariño entre hermanos, convencido de que para la amistad era muy importante tanto el haber nacido de los mismos progenitores como el criarse juntos. ${ }^{188}$

Cabe mencionar que el historiador se queja de que en su época los atenienses ya no respetan a los ancianos, ni siquiera a sus propios padres. ${ }^{189}$ Acerca de la actitud que uno debe mantener con sus progenitores o con cualquier otra persona, Sócrates sostiene que, en lugar de confiar en que son nuestros parientes y no ameritan mayor cuidado, hay que procurar ser útiles a todos aquellos cuyo aprecio deseamos. ${ }^{190}$ Por todo esto, el no cuidar a los padres también denota un acto que, además de ingrato, resulta injusto, de ahí que fuera tan penado entre los atenienses, al grado de que se castigaba con la atimía. ${ }^{191}$

${ }^{187}$ Ibid., I, 2, 48. Como se puede percibir, "Jenofonte usa philía para referirse tanto a lo que está al interior y al exterior del círculo familiar. Con base en Memorables, se puede ver que, al igual que Aristóteles, Jenofonte se interesa por varias clases de philía. Platón, Jenofonte y Aristóteles abordan el tema de la amistad como una subparte de la philía, concibiéndola como el lazo entre padres e hijos, amigos, o miembros de una comunidad más grande. Desde esta perspectiva, la amistad es una de las varias relaciones que asocia a los individuos en la polis" (Konstan 1997, pp. 91-92).

${ }^{188}$ Mem., II, 3, 4. En II, 3, 1-17, Sócrates se afana por reconciliar a dos hermanos que estaban distanciados, al subrayar la trascendencia del amor fraterno. Al respecto, el sustantivo phílos, traducido por lo común como "amigo", también puede aludir a ciertas relaciones de parentesco o a aquellas que se desarrollan entre ciudadanos (Enjuto Sánchez 2009, pp. 88-89). La amistad no necesariamente implica lazos de sangre o etnicidad, más bien obedece a la buena voluntad (benevolencia) hacia uno (Konstan 1997, p. 58).

${ }^{189} \mathrm{Mem} ., \mathrm{III}, 5$, 15. Jenofonte trata de fomentar el respeto hacia los mayores, al afirmar que los persas antiguos se distinguían por su obediencia y por su respeto no sólo hacia sus dirigentes, sino también hacia las personas de avanzada edad (Cyr., II, 4, 6). Agrega que Ciro el Viejo fue educado para cederles el paso, el asiento y la palabra a los mayores; de igual forma él les inculcó a sus hijos que honraran a los ancianos y que recibieran honores de los muchachos (VIII, 7, 10). Por otra parte, el historiador subraya que Ciro el Joven era el más respetuoso de los de su edad y obedecía mejor a los ancianos que sus compañeros de condición inferior (An., I, 9, 5).

\footnotetext{
190 Mem., I, 2, 55.

${ }^{191}$ Ibid., II, 2, 13-14.
} 
$\mathrm{Al}$ respecto, el sabio aclara que honrar a los progenitores era una ley universal. ${ }^{192}$ En cuanto a la gratitud que le deben los hijos a los padres, en Memorables, Sócrates intenta que su hijo mayor Lamprocles se contente con Jantipa; pues considera que los progenitores le hacen el mayor beneficio a sus hijos, al darles el ser. ${ }^{193}$ Tras pronunciar un elogio de la maternidad, el filósofo le hace ver al joven que el mal carácter de su madre es tolerable, y que, si es incapaz de soportarla a ella, menos podrá honrar, obedecer y complacer a alguien más, como por ejemplo a un general o a un magistrado. ${ }^{194}$

El filósofo le señala a su primogénito que Jantipa, que lo quiere mucho y desea su bien, es quien más merece que la honre. Advierte que la ciudad no sanciona a los malagradecidos, pero sí castiga a quienes no respetan a sus padres, al inhabilitarlos y excluirlos de los cargos públicos; porque un hombre ingrato no puede realizar acciones bellas y justas, ni siquiera sus ofrendas a los dioses serían piadosas. Enfatiza que los atenienses son tan estrictos en cuanto a los deberes para con los padres, que también vigilan que los hijos cuiden las tumbas de sus progenitores. ${ }^{195}$ Con base en todo esto, Sócrates le recomienda a Lamprocles que incluso se disculpe con las divinidades por enojarse con su madre, y que procure que los demás no se enteren de su falta de atención hacia sus padres, para que no lo desprecien todos y lo abandonen sus amigos, pues se piensa que quien es malagradecido con sus papás también es incapaz de corresponder a un favor. ${ }^{196}$

\section{Conclusiones}

Como afirma José María Zamora Calvo, si bien en la actualidad no se le concede tanta trascendencia a la philía, porque a menudo se piensa que se limita al ámbito privado, cabe recordar que los filósofos antiguos con-

192 Mem., IV, 4, 20.

${ }^{193}$ Ibid., II, 2, 1-3.

${ }^{194}$ Ibid., II, 10-11.

195 Ibid., II, 2, 13. El ateniense se casaba para engendrar hijos que lo cuidaran durante su vejez y que honraran la memoria de sus ancestros. Iscómaco le dice a su joven esposa que, si la divinidad les concede tener hijos, ambos pensarán en la manera más conveniente de educarlos, ya que son un bien común de los esposos, así se procuran los mejores aliados y el mejor sostén para su vejez (Oec., VII, 12).

${ }^{196}$ Mem., II, 2, 14. 
sideraron a la amistad como una virtud fundamental, no nada más por el lugar que ocupa en la vida moral del ser virtuoso, sino también por la función tan importante que ejerce en la constitución y consolidación de las ciudades. ${ }^{197}$

A mi juicio, al igual que sus contemporáneos Isócrates y Platón, Jenofonte lamenta el ambiente turbulento y caótico de Atenas. Como no está de acuerdo con el individualismo de su época, dirige su esfuerzo intelectual a encontrar una manera de integrar la excelencia individual con la estructura de la mayoría, ${ }^{198}$ de ahí que, ante tan desolador panorama, asuma el reto de superar la creciente división social al fomentar la convivencia armónica a través de sus obras y de varios personajes clave, entre los cuales destaca Sócrates.

La propuesta jenofóntica es digna de tomarse en cuenta sobre todo en nuestros días, donde la amistad y la gratitud parecen irrelevantes y las relaciones humanas son cada vez más superficiales y problemáticas. Aunado a lo anterior padecemos un ambiente de gran inseguridad y alto índice de criminalidad.

En estos momentos tan críticos, los clásicos todavía tienen mucho que enseñarnos. Por eso conviene remontarnos al siglo IV a. C., cuando el exiliado ateniense estaba convencido de que al poner en práctica la

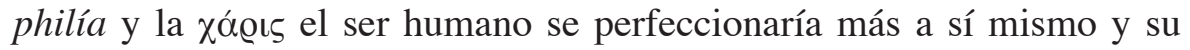
comportamiento redundaría en una mayor cohesión, una convivencia social armónica, y sobre todo una estabilidad social. De esta manera, la amistad y la gratitud se convierten en virtudes éticas esenciales no sólo a nivel individual, sino también a nivel social, pues gracias a ellas se crean vínculos sólidos entre los ciudadanos, lo cual repercute favorablemente en el ámbito público.

En suma, para Jenofonte y su maestro Sócrates, lo más importante es transformar a los hombres en seres "bellos y buenos", esto es en mejores personas y buenos amigos, lo que equivale a buenos ciudadanos, cuya incidencia en su sociedad sea positiva; porque únicamente así se pueden desterrar terribles males como la intolerancia, el individualismo, la envidia, la apatía y la violencia, entre otros.

197 Zamora Calvo 2009, p. 7.

198 Seager 2001, pp. 396-397. 


\section{BIBLIOGRAFÍA}

Textos de Jenofonte

Jenofonte, Anábasis, introducción de Carlos García Gual, traducción y notas de Ramón Bach Pellicer, Madrid, Gredos, 1991 (Biblioteca Clásica Gredos, 52).

-, Ciropedia, introducción, traducción y notas de Ana Vegas Sansalvador, Madrid, Gredos, 1987 (Biblioteca Clásica Gredos, 108).

-, Obras menores (Hierón, Agesilao, La República de los lacedemonios, Los ingresos públicos, El jefe de la caballería, De la equitación, De la caza). PSEUdo Jenofonte, La República de los atenienses, introducciones, traducciones y notas de Orlando Guntiñas Tuñón, Madrid, Gredos, 1984 (Biblioteca Clásica Gredos, 75).

-, Recuerdos de Sócrates, Económico, Banquete, Apología de Sócrates, introducciones, traducciones y notas de Juan Zaragoza, Madrid, Gredos, 1993 (Biblioteca Clásica Gredos, 182).

Senofonte, Ipparchico. Manuale per il comandante di cavalleria, introduzione, traduzione e note di Corrado Petrocelli, appendice P. G. Joly de Maizeroy. Quadro generale della cavalleria greca, Bari, Edipuglia, 2001 (Quaderni di "Invigilata lucernis", 14).

XÉNOPHON, Le commandant de la cavalerie, texte établi et traduit Édouard Delebecque, Paris, Société d'Édition "Les Belles Lettres", 1973.

Xenophon, Anabasis, Books IV-VII, english translation by Carleton L. Brownson, Symposium and Apology, O. J. Todd, Cambridge, Harvard University Press, 1947 (The Loeb Classical Library).

-, Memorabilia, Oeconomicus, english translation by E. C. Marchant, Symposium, Apology, O. J. Todd, Cambridge, Harvard University Press, 2002 (The Loeb Classical Library).

-, Scripta minora, english translation by E. C. Marchant, Cambridge, Harvard University Press, 1946 (The Loeb Classical Library).

-, The Education of Cyrus, translated and annotated by Wayne Ambler, New York, Cornell University Press, 2001.

\section{Estudios especializados}

Anderson, J. K., Xenophon, London, Bristol Classical Press, 2001 (1974).

CANFORA, Luciano, Una profesión peligrosa. La vida cotidiana de los filósofos griegos, Barcelona, Anagrama, 2002.

DAGUERRE, Martín, "Sobre el valor de la amistad y su conflicto potencial con la moral. Una revisión del debate contemporáneo", Diánoia, LV/64, mayo, 2010, pp. 47-69. <http://dianoia.filosoficas.unam.mx/info/2010/DIA64_Daguerre.pdf $>$. [Consulta: 15 de octubre de 2013.]

Enjuto SÁncheZ, Begoña, "Amistad y relaciones sociales en el Mundo Antiguo. Una aproximación al fenómeno en el mundo griego y romano", Es- 
pacio, tiempo y forma, UNED, Serie II, Historia Antigua, t. 22, 2009, pp. 85-96. <http://e-spacio.uned.es/fez/eserv.php?pid=bibliuned:ETFSerieII-200922-2060\&dsID=Documento.pdf $>$. [Consulta: 31 de octubre de 2013.]

Fernández Caraballo, Ana Ma., "Sobre Eros y Philía en la enseñanza", en Segundo Congreso Latinoamericano de Filosofía de la Educación, Montevideo, Universidad de la República, 2013, pp. 67-75. <http://brendanlai.tempsite.ws/ alfefilosofiadelaeducacion/files/ProgramaeConfer\%C3\%AAnciasIICongresso 2013.pdf $>$. [Consulta: 31 de octubre de 2013.]

FERruCCI, Stefano, "L'oikos nelle leggi della polis. Il privato ateniese tra diritto e società", Etica \& Political Ethics \& Politics, IX, 2007, 1, pp. 135-154. <www. 2.units.it/retica/2007_1/FERRUCCI.pdf>. [Consulta: 30 de noviembre de 2013.] Herman, Gabriel, Ritualised Frienship and the Greek City, Cambridge, Cambridge University Press, 1987.

Hornblower, Simon, El mundo griego 479-323 a. C., traducción de Teresa Sempere y Jordi Beltrán, Barcelona, Editorial Crítica, 1985.

JAEGER, Werner, Paideia. Los ideales de la cultura griega, II, versión española de Wenceslao Roces, México, Fondo de Cultura Económica, 1944.

Konstan, David, Friendship in the Classical World, Cambridge, Cambridge University Press, 1997.

LLEDó Í̃̃IGO, Emilio, “Amistad y memoria”, en José María Zamora Calvo (ed.), La amistad en la filosofía antigua, Madrid, Ediciones de la Universidad Autónoma de Madrid, 2009 (Colección de Estudios), pp. 19-30.

LORCH, Benjamin, "Xenophon's Socrates on Political Ambition and Political Philosophy", The Review of Politics, 72, 2010, pp. 189-211. <http://journals.cambridge.org/action/displayFulltext?type $=1 \&$ fid $=7799360 \&$ jid=ROP \&volumeId= 72\&issueId=02\&aid=7799358>. [Consulta: 30 de noviembre de 2013.]

Marein, M. F., "L'Économique du Xenophon: Traité de morale? Traité de propagande?", Bulletin de l'Association de Guillaume Budé, 1993, pp. 226-244.

Mitchell, Lynette G., Greeks Bearing Gifts. The Public Use of Private Relationships in the Greek World, 435-323 BC, Cambridge, Cambridge University Press, 1997.

Ober, Josiah, Mass and Elite in democratic Athens. Rhetoric, Ideology, and the Power of the People, Princeton, Princeton University Press, 1989.

Olivares Chávez, Carolina, Ética y milicia en Acerca del Hiparco de Jenofonte, estudio, traducción y notas, tesis de Maestría en Letras Clásicas, México, Universidad Nacional Autónoma de México-Facultad de Filosofía y Letras, 2005 (inédita).

-, Jenofonte: su propuesta de paideia a partir de tres personajes atenienses, México, Universidad Nacional Autónoma de México, 2014 (Cuadernos del Centro de Estudios Clásicos, 53).

Plácido SuÁrez, Domingo, "Economía y Sociedad: Polis y Basilea, los fundamentos de la reflexión historiográfica de Jenofonte", Habis, 20, 1989, pp. 135-154. $<$ http://dialnet.unirioja.es/servlet/extaut?codigo=103636>. [Consulta: 20 de octubre de 2013.] 
Plácido SuÁrez, Domingo, "Las relaciones de amistad en la ciudad griega, entre arcaísmo y helenismo", Revista Digital de la Escuela de Historia, 4/6, 2012, pp. 35-46. <http://web2.rosario-conicet.gov.ar/ojs/index.php/RevPaginas/article/view/174/0>. [Consulta: 31 de octubre de 2013.]

Salay, Paul W., Socrates the Whipping Post: Xenophon's Portrayal of Socrates as a Rebuke of Athenian Society, tesis de Maestría en Artes, Long Beach, California State University, 2004.

Santiago Martínez, Lourdes, "Amistades útiles y amigos leales. Tipos de amistad en la Antigüedad clásica”, en Luis Fernando Lara, Reynaldo Yunuen Ortega y Martha Lilia Tenorio (eds.), De amicitia et doctrina. Homenaje a Martha Elena Venier, México, El Colegio de México, 2007, pp. 329-346.

SEAGER, Robin, "Xenophon and Athenian democratic ideology", Classical Quarterly, 51/2, 2001, pp. 385-397.

Solana Dueso, José, "La philía entre eros y dike", Convivium, 20, 2007, pp. 2336. <www.raco.cat/index.php/convivium/article/viewFile/73251/98880>. [Consulta: 20 de noviembre de 2013.]

- , "Philía: entre eros y dike", en José María Zamora Calvo, La amistad en la filosofía antigua, Madrid, Ediciones de la Universidad Autónoma de Madrid, 2009 (Colección de Estudios), pp. 31-41.

Strauss, Leo, Sobre la tiranía. Seguido del debate Strauss-Kojève, presentación y traducción de Leonardo Rodríguez Duplá, Madrid, Ediciones Encuentro, 2005.

VAllejo CAmpos, Álvaro, "Éros y philía en Platón y Aristóteles", en José María Zamora Calvo (ed.), La amistad en la filosofía antigua, Madrid, Ediciones de la Universidad Autónoma de Madrid, 2009 (Colección de Estudios), pp. 63-78.

TemPle, Dominique, Teoría de la reciprocidad, t. I. La reciprocidad y el nacimiento de los valores humanos, Javier Medina y Jacqueline Michaux (eds.), La Paz, Bolivia, Artes Gráficas Editorial "Garza Azul”, 2003.

Zamora CAlvo, José María (ed.), La amistad en la filosofía antigua, Madrid, Ediciones de la Universidad Autónoma de Madrid, 2009 (Colección de Estudios). 